\title{
"A Grand and Patriotic Pilgrimage": The Iowa Civil War Monuments Dedication Tour of 1906
}

\author{
WILLIAM C. LOWE
}

OVER THE PAST DECADE AND A HALF, the American Civil War has followed World War I and the Holocaust into what historian Jay Winter has labeled the "Memory Boom." Historians, sociologists, geographers, and other scholars have shown increasing interest in how the memory of the war has been shaped by a variety of influences and commemorative practices. $^{2}$ The current historiography of Civil War memory is dominated by David Blight's Race and Reunion, which stresses the extent to which in the post-Reconstruction era the memory of the war was shaped by a powerful impulse towards recon-

I thank the State Historical Society of Iowa for a 2006-7 Research Grant and Ashford University for a sabbatical leave during spring semester 2007. I am also grateful to the editor of The Annals of Iowa and the journal's anonymous readers for their helpful comments on an earlier draft.

1. Jay Winter, "The Memory Boom in Contemporary Historical Studies," Raritan 21 (2001), 52-66. See also the introduction to Winter's Remembering War: The Great War between History and Memory in the Twentieth Century (New Haven, CT, 2006), 1-13, where he notes that the term "collective memory" has become so elastic as to lose much of its usefulness; he prefers the term "collective remembrance" to denote "what groups of people do when they act in public to conjure up the past" (5).

2. See the works discussed in Matthew J. Grow, "The Shadow of the Civil War: A Historiography of Civil War Memory," American Nineteenth-Century History 4 (2003), 77-103; and Christopher Waldrep, "Memory, History, and the Meaning of the Civil War: A Review Essay," Register of the Kentucky Historical Society 102 (2004), 383-402.

THE ANNALS OF IOWA 69 (Winter 2010). (C) The State Historical Society of Iowa, 2010. 
ciliation by white northerners and white southerners, a process that overwhelmed any tendency to remember the war in what Blight calls "emancipationist" terms. The latter remained alive mainly in the African American community. ${ }^{3}$ The tendency to cast the war's remembrance in terms of a tension between emancipation and reconciliation is perhaps further strengthened by the growing body of evidence in writing on the war itself that stresses the degree to which soldiers on both sides saw slavery in one way or another as being central to the war's purpose. ${ }^{4}$

One source commonly used for the study of remembrance is the monument, a cultural artifact that embodies a direct attempt by the present to determine how the future will remember the past. Scholars have established the overall pattern of Civil War memorialization, with particular emphasis on the prevalence of the private (white) soldier as the dominant figurative form and the role of monument building in fostering the Lost Cause in the postwar South. ${ }^{5}$ Although often mentioning the states, historians have paid relatively little explicit attention to the role of state governments in shaping Civil War commemoration. ${ }^{6}$

Iowa, like many northern states, dedicated monuments to its troops on Civil War battlefields, though it did so later than many and appears to have been unique in doing so as part of a single tour. In November 1906 Governor Albert Baird Cummins

3. David Blight, Race and Reunion: The Civil War in American Memory (Cambridge, MA, 2001). See also James H. Madison, "Civil War Memories and 'Pardnership Forgittin', 1865-1913," Indiana Magazine of History 99 (2003), 198-230; and Leslie A. Schwalm, "Emancipation Day Celebrations: The Commemoration of Slavery and Freedom in Iowa," Annals of Iowa 62 (2003), 291-332.

4. See, for example, James M. McPherson, For Cause and Comrades: Why Men Fought in the Civil War (New York, 1997); and Chandra Manning, What This Cruel War Was Over: Soldiers, Slavery, and the Civil War (New York, 2007).

5. See, for example, James M. Mayo, War Memorials as Political Landscape: The American Experience and Beyond (New York, 1988), esp. 170-91; G. Kurt Piehler, Remembering War the American Way (Washington, DC, 1995), esp. 46-87; Thomas J. Brown, The Public Art of Civil War Commemoration: A Brief History with Documents (Boston, 2004); Kirk Savage, Standing Soldiers, Kneeling Slaves: Race, War, and Monument in Nineteenth-Century America (Princeton, NJ, 1997); and Monuments to the Lost Cause: Women, Art, and the Landscapes of Southern Memory, ed. Cynthia Mills and Pamela H. Simpson (Knoxville, TN, 2003). Blight's Race and Reunion does not make extensive use of monuments as source material (2).

6. An exception to this generalization is Madison, "Civil War Memories and 'Pardnership Forgittin'. 
and approximately 160 others embarked on a two-week tour by chartered train, called "the Governor's Special," that took them from Iowa to Vicksburg, Mississippi; Andersonville, Georgia; and Chattanooga and Pittsburg Landing (Shiloh), Tennessee, where they dedicated monuments to Iowa Civil War troops. The expedition offers an opportunity to examine the process by which a state sought to memorialize and shape the memory of its role in the Civil War. The tour can be viewed in a variety of contexts: as a response to the federal government's efforts to preserve Civil War battlefields, as a case study in the construction of official (as opposed to vernacular) memory, as an episode in Iowa politics, and as a contribution to sectional reconciliation. Above all, perhaps, it can be seen as an effort by influential and aging - veterans to define their war in the terms they wished to pass down to posterity.

In this article I examine the process by which the state of Iowa erected the monuments, the planning and execution of the tour that dedicated them, and the view of the war embodied in this act of collective remembrance. Two main points emerge from this examination. First, the veterans who did the most to shape the form and character of Iowa's battlefield memorialization were not particularly typical of the state's veteran population. Second, although it would not be appropriate to characterize their efforts as "emancipationist," neither were they wholly "reconciliationist." Instead, they incorporated elements of both of those tendencies in a discourse of remembrance that sought to cast the war in stone - literally - as first and foremost a struggle to preserve the American Union.

PORTIONS OF THE BATTLEFIELD AT GETTYSBURG had been subject to preservation efforts almost from the morrow of the battle, but such efforts were not matched on other fields until well after the war. ${ }^{7}$ The movement to preserve and mark at least some of the other major battlefields using the power of the federal government was begun by Union veterans of the Army of the Cumberland, especially Generals Ferdinand Van Derveer

7. See Jim Weeks, Gettysburg: Memory, Market, and an American Shrine (Princeton, NJ, 2003) and the sources cited therein. 
and Henry Van Ness Boynton of Ohio. Their efforts originally aimed to preserve the battlefield at Chickamauga as a memorial to the men who had fought on both sides - in contrast to Gettysburg, where originally only the Union lines had been marked and memorialized. ${ }^{8}$ No Iowa regiments fought at Chickamauga, but Iowans became involved as memorialization efforts came to include the nearby battlefields around Chattanooga, where Iowa units of the Army of the Tennessee had fought in November 1863. Congress created the Chickamauga and Chattanooga National Military Park in 1890, then authorized another at Antietam. The creation of a park at Shiloh followed in 1894, with Iowa veteran David W. Reed playing a prominent role and the Iowa congressional delegation providing strong political support. ${ }^{9}$ Gettysburg became the fourth federally administered park in 1895, when the Gettysburg Battlefield Memorial Association turned over its holdings to the government. ${ }^{10}$ The last of the five original battlefield parks was Vicksburg, authorized in 1899 - the next group of Civil War parks would not be established until the $1920 \mathrm{~s}^{11}$ - with Iowa veterans John Festus Merry, William Titus Rigby, and J. K. P. Thompson playing prominent roles and the Iowa congressional delegation again giving strong support. ${ }^{12}$

\footnotetext{
8. H. V. Boynton, The National Military Park, Chickamauga-Chattanooga: An Historical Guide with Maps and Illustrations (Cincinnati, 1895), chaps. 16-18. On the development of the early battlefield parks, see Timothy B. Smith, The Golden Age of Battlefield Preservation: The Decade of the 1890s and the Establishment of America's First Five Military Parks (Knoxville, TN, 2008); and Ronald F. Lee, The Origin and Evolution of the National Military Park Idea (Washington, DC, 1973), esp. chap. 3, "The First Battlefield Parks, 1890-1899," accessed online 4/5/2005 at www.nps.gov/history/history/online_books/history_military/index.htm; and Richard West Sellars, Pilgrim Places: Civil War Battlefields, Historic Preservation and America's First National Military Parks, 1863-1900 (Washington, DC, 2005).

9. On Reed's role, see Timothy B. Smith, "David Wilson Reed: The Father of Shiloh National Military Park," Annals of Iowa 62 (2003), 333-59. On the Shiloh park generally, see idem, This Great Battlefield of Shiloh: History, Memory, and the Establishment of a Civil War National Military Park (Knoxville, TN, 2004); and idem, The Untold Story of Shiloh: The Battle and the Battlefield (Knoxville, TN, 2006). See also idem, "The Politics of Battlefield Preservation: David B. Henderson and the National Military Parks," Annals of Iowa 66 (2007), 293-320.

10. Weeks, Gettysburg, 60-61.

11. See Smith, Golden Age of Battlefield Preservation, 211-12.

12. See Christopher Waldrep, Vicksburg's Long Shadow: The Civil War Legacy of Race and Remembrance (Lanham, MD, 2005), esp. chap. 4, "The Boys from Iowa";
} 
Merry, assistant chief passenger agent for the Illinois Central Railroad, was generally credited with originating the idea of a battlefield park at Vicksburg and took pride in the soubriquet "father of the Vicksburg Park." ${ }^{13}$ Rigby moved to Vicksburg to become one of three federal park commissioners. ${ }^{14}$ Iowans had thus been involved in creating three of the first five battlefield parks, and had played critical roles at Shiloh and Vicksburg.

It was intended from the beginning that the parks would both mark the positions of the opposing forces so that visitors could better understand the battles and that the states would follow with appropriate monuments. ${ }^{15}$ The ChickamaugaChattanooga park set a precedent for the process. First, stateappointed commissions cooperated with federal park commissions to mark the troop positions. Once those were approved by the park commissioners and the secretary of war, the federal government erected cast iron markers of uniform design. The states were then invited to erect appropriate monuments fol-

Smith, Golden Age of Battlefield Preservation, chap. 7; and Terrence J. Winschel, "Stephen D. Lee and the Making of an American Shrine," Journal of Mississippi History 63 (2001), 17-32. Nine Iowans were among the 50 charter members of the Vicksburg National Park Association, organized in November 1895 to lobby for the park's creation. "List of Subscribers to Capital Stock of the Vicksburg National Park Association, Nov. 4, 1895," William T. Rigby Papers, Special Collections, University of Iowa Libraries, Iowa City (hereafter cited as UISC). Thompson, of Rock Rapids, is generally neglected in the above accounts. See his "Iowa at Vicksburg and the Vicksburg National Military Park," Annals of Iowa 5 (1902), 272-92. Within the state, Thompson, GAR Department Commander for Iowa in 1895-96, cultivated press coverage of the movement to create the park, circularized the state GAR to support it, and lobbied the state legislature to support the park project and to consider a sizable appropriation for commemorative purposes. See Thompson's letters to R. L. Chase, Department Assistant Adjutant General in 1895 and 1896, Monuments - Vicksburg file, GAR Collection, State Historical Society of Iowa, Des Moines (hereafter cited as SHSI-DM). On Thompson generally, see Jacob A. Swisher, comp., The Iowa Department of the Grand Army of the Republic (Iowa City, 1936), 94-95.

13. On Merry, see Waldrep, Vicksburg's Long Shadow, 144-46; and Benjamin F. Gue, Biographies and Portraits of the Progressive Men of Iowa, 2 vols. (Des Moines, 1899), 2:243-45.

14. On Rigby, see his papers, esp. boxes 3 and 4, UI-SC; Waldrep, Vicksburg's Long Shadow, 160-71; and Michael Wilson Panhorst, "Lest We Forget: Monuments and Memorial Sculpture in National Military Parks on Civil War Battlefields, 1861-1917" (Ph.D. diss., University of Delaware, 1988), 60-62.

15. Boynton, National Military Park, 255-56. 
lowing federal regulations. ${ }^{16}$ Monuments might be planned by the same or by a second state commission. Once the park commission and the War Department approved the designs and inscriptions, monuments could be erected and dedicated. ${ }^{17}$

Iowa's battlefield monuments can be seen as part of a statelevel arc of commemoration that helped to define the war's meaning through monument raising and other activities. Monument building began first and continued longest at the local level, but the state itself began to get involved in the 1880s. In 1884 the General Assembly passed a law allowing counties to use public funds to erect monuments. ${ }^{18}$ In 1894 the battle flags of Iowa Civil War regiments were moved from the state arsenal and placed with appropriate ceremony in the capitol. ${ }^{19}$ The state's largest and single most expensive commemorative effort came, also in 1894, with the erection of the Soldiers and Sailors Monument south of the capitol at a cost of $\$ 150,000$. The latter, however, proved a controversial process, especially when it came to selecting the individuals whose images would be on the medallions that circled the monument. ${ }^{20}$

16. Ibid., 270-71. These stipulated acceptable materials, required that monument foundations be laid by the park engineer, and established guidelines for inscriptions. The latter had to be "purely historical," specific to the battle or campaign, and "based upon, and conform to" official reports.

17. See Panhorst, "Lest We Forget," chap. 2.

18. Acts and Resolutions of the Twentieth General Assembly (Des Moines, 1884), chap. 162. The 1884 law was replaced in 1886 with an act requiring a referendum before a county could levy a tax to erect a monument or build a memorial hall. Acts and Resolutions of the Twenty-first General Assembly (Des Moines, 1886), chap. 62.

19. "Battle Flag Day," August 10, 1894: Ceremonials Attending the Transfer of the Battle Flags of Iowa Regiments from the Arsenal to the Capitol (Des Moines, 1894). The flags were moved again in 1905 from the second (legislative) floor of the capitol to the first (main) floor so that more people could see them. Cedar Rapids Weekly Gazette, 9/5/1905.

20. Cora Chaplin Weed, Hand Book for Iowa Soldiers' and Sailors' Monument, Centennial Edition (1897; reprint, Iowa City, 1994); James Harlan, "The Iowa Soldiers' and Sailors' Monument," Midland Monthly 5 (Feb. 1896), 98-112. D. N. Richardson, secretary of the commission that erected the monument, observed that there was no objection in the legislature until the commission announced "that the list was full. ... Could we have proceeded to place medallions in excess of the design (35) there would have been no trouble." Richardson to Alonzo Abernethy, 10/16/1897, Abernethy Papers, SHSI-DM. There were many complaints that southeastern Iowa was overrepresented on the monument. 
In 1894 the Iowa General Assembly, responding to lobbying by veterans, authorized appointment of a five-member commission to locate the positions occupied by Iowa troops in the battles around Chattanooga. Chaired by Major Joseph D. Fegan of Clinton, the commission issued its report in 1896. Requesting "the same treatment that the soldiers from other states are getting," it recommended that in addition to tablets marking the positions of Iowa units the state should erect four monuments at a cost of $\$ 25,000 .{ }^{21}$ The General Assembly, however, took no immediate action to erect battlefield monuments.

Commissions to mark the positions of Iowa troops at Shiloh and Vicksburg followed in 1895 and 1899. The report of the former called on the state to erect markers and monuments "inferior to none ... that visitors to this National park . . will read and know what Iowa and her soldier citizens did for their country in its time of greatest need." The Vicksburg marking commission issued its report in December 1901. Characterizing the Vicksburg park as "the conception of Iowa men," it emphasized that more Iowa units had been engaged at Vicksburg than in any other campaign of the war and that they had sustained almost 23 percent of Union casualties. ${ }^{22}$

In 1900, on the thirty-eighth anniversary of the Battle of Shiloh, the legislature appropriated $\$ 50,000$ to erect state and regimental monuments there. Governor Leslie M. Shaw promptly appointed the 11 members of the commission, five of whom had been members of the Shiloh marking commission. Politics

21. Report of the Iowa Commissioners of Chickamauga and Chattanooga National Military Park (Des Moines, 1896), 6. The Burlington GAR post sent out a circular letter to other posts asking them to pass resolutions supporting an appropriation for monuments on Lookout Mountain and Missionary Ridge. Samuel Peabody and F. J. Disque to Post Commanders, 2/12/1896, Memorial Hall file, GAR Collection, SHSI-DM. See also C. R. Mackenzie to Alonzo Abernethy, 10/27/1906, Abernethy Papers, on the efforts of J. D. Fegan and himself to lobby the legislature 13 years earlier.

22. Report of the Shiloh Battlefield Commission to the Governor of Iowa, December 3, 1895 (Des Moines, 1896), 4; Commissioners' Report: Commission to Locate the Position of Iowa Troops at the Siege of Vicksburg (Des Moines, 1901), 11-14, 39-40. The 11-member Shiloh commission, chaired by Col. William T. Shaw of Anamosa, recommended that $\$ 100,000$ be appropriated for the Shiloh markers and monument. The 35-member Vicksburg commission, chaired by J. K. P. Thompson, recommended an appropriation of $\$ 150,000$ to erect one "elaborate" state monument and monuments for each regiment and battery. 
appear to have played a part in the selection process. John Hayes, commission secretary, later recalled that more prominent veterans from one regiment had been passed over in favor of one who was "a hustler at the primaries." ${ }^{23}$

The Shiloh monument commission was to have a contentious history. Its work began uneventfully. E. B. Soper of Emmetsburg was chosen as permanent chairman. ${ }^{24}$ After visiting the battlefield, the commission selected a design by Frederick Triebel for the state monument and a standard design from the firm of Shenan and Flavin for the regimental monuments. Triebel's design featured a 36-foot-high shaft surmounted by an eagle and incorporated bronze decorations of a commemorative wreath and a twelve-and-a-half-foot allegorical female figure of Fame inscribing the deeds of Iowa troops on the shaft. ${ }^{25}$ A tentative dedication date of Memorial Day, 1903, was set. Trouble, however, developed with Triebel's bronzes, and the monument was not accepted until August, necessitating postponement of the dedication. Ultimately, however, Soper pronounced it "a beauty, the pride of Shiloh National Park."

The difficulties with Triebel's bronzes paled in comparison with the four-year-long controversy that arose between the state monument commission and the federal park commission over inscriptions on two of the regimental monuments. At issue was the time of day when the 15th and 16th Iowa became engaged

23. Acts and Resolutions of the Twenty-eighth General Assembly (Des Moines, 1900), chap. 137; J. H. Munroe to C. W. Kepler, 12/8/1899, Kepler Papers, State Historical Society of Iowa, Iowa City (hereafter SHSI-IC); E. B. Soper to C. W. Kepler, 1/17/1900, ibid.; W. H. Fleming to C. W. Kepler, 4/25/1900, ibid.; John Hayes to C. W. Kepler, 1/2/1913, ibid.

24. G. L. Godfrey to C. W. Kepler, 5/14/1900, 11/5/1900, ibid.; John Hayes to C. W. Kepler, 8/10/1900, ibid.; Godfrey and John Hayes to Kepler, 11/6/1900, ibid. On Soper, see Johnson Brigham, Iowa: Its History and Its Foremost Citizens, 3 vols. (Chicago, 1915), 3:1393.

25. John Hayes to C. W. Kepler, 3/19/1901, 4/19/1901, ibid; Smithsonian American Art Museums, Inventory of American Sculpture (hereafter Smithsonian, IAS) accessible online at http://siris-artinventories.si.edu. On Triebel, see Adelaide N. Cooley, The Monument Maker: A Biography of Frederick Ernst Triebel (Hicksville, NY, 1978).

26. The ups and downs of Triebel's relationship with the commission can be followed in E. B. Soper's correspondence with C. W. Kepler, in the Kepler Papers, which contain copies of letters to and from Triebel in 1903. 


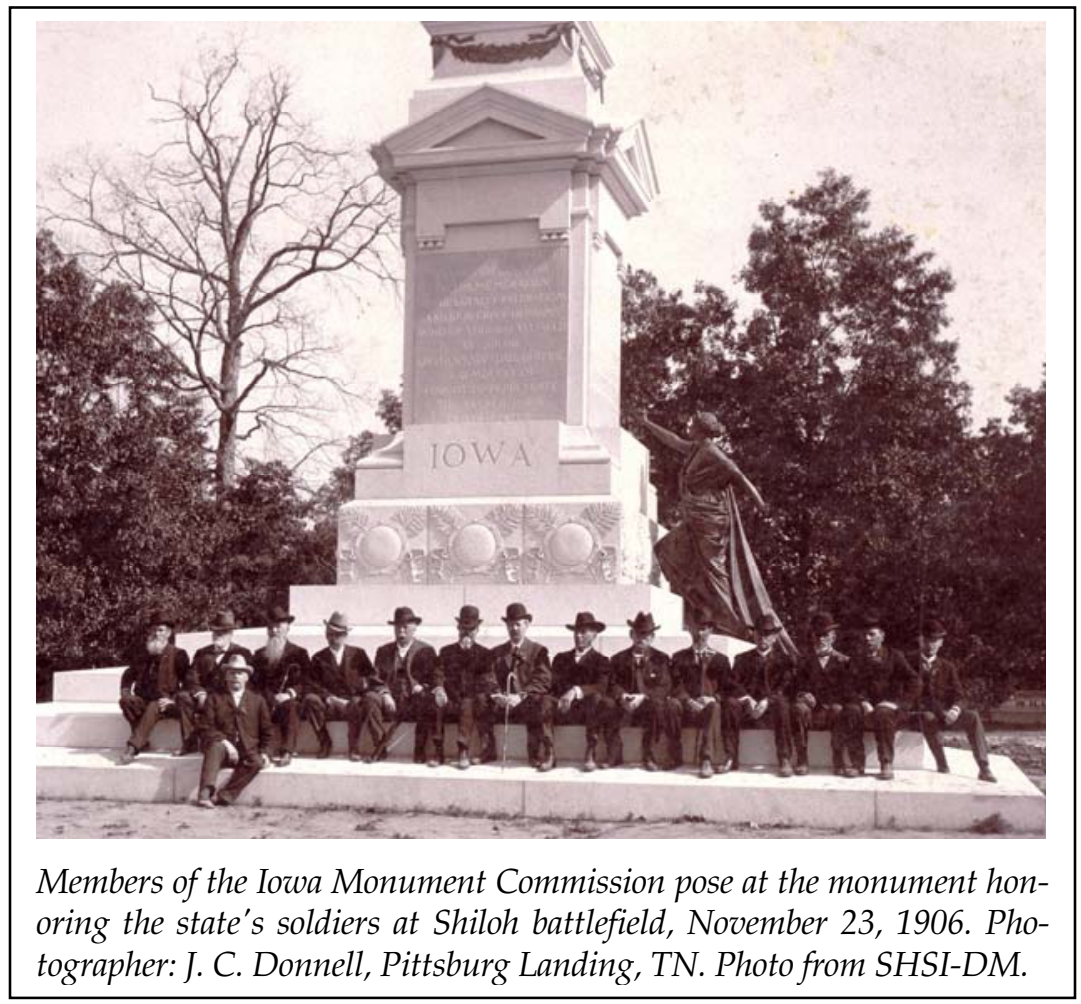

on the Union right on the battle's first day. ${ }^{27}$ The regimental commissioners forwarded inscriptions based on the reports of their commanders that placed the regiments in action at 10:00 and 10:30 a.m., respectively. David W. Reed, the secretary and historian of the federal park commission, who was regarded as the foremost authority on the battle, rejected the inscriptions, citing their inconsistency with the reported actions of other units, and put forward alternative inscriptions that placed the units in action after noon. Veterans of the two regiments regarded this as an affront to the honor of their officers, a misrep-

27. The following account of the Shiloh inscriptions controversy is based on material in the Kepler Papers; the Ainsworth Collection, SHSI-DM; the Henry Clay McArthur Papers, SHSI-DM; the Albert Baird Cummins Papers, SHSIDM; the William Boyd Allison Papers, UI-SC; John Hayes's account in The Iowa Official Register (Des Moines, 1906), 176-80; and Smith, Great Battlefield of Shiloh, 83-84. Only direct quotations are individually cited. 
resentation of their battlefield experience, and discriminatory treatment in that other regiments were allowed inscriptions based on their commanders' reports. They refused to accept Reed's suggestions. Their cause was taken up by Crocker's Iowa Brigade Association, one of the state's best-organized and most visible veterans' organizations, and by the great majority of the state monument commission, with chairman Soper (who had served with Reed in the 12th Iowa) a notable exception. The veterans appealed to Governor Cummins, who gave them the benefit of his considerable legal skills. Despite two trips to Washington and a six-hour oral argument at the Shiloh park, however, the governor's efforts also failed. The controversy became increasingly bitter. Reed characterized it as an "absurdity," and some of the commissioners began to refer to him as "the little pig-headed Reed." ${ }^{28}$ In late 1905 Iowa's powerful congressional delegation, led by Representative Walter I. Smith and Senator William Boyd Allison, weighed in. In March 1906 Secretary of War William Howard Taft ordered compromise inscriptions prepared that placed the two regiments in action in the morning "as reported by" their officers. The Iowa Shiloh commissioners regarded this as vindication. ${ }^{29}$

The resolution of the inscription controversy did not end the acrimony, however. Chairman Soper's lack of support rankled many of the commission members and eventually turned into a belief that he had joined with Reed to deny justice to the 15th and 16th. "They are toting together," wrote Charles Kepler, commissioner from the 13th Iowa. During the summer of 1906, a majority of the commission voted to depose Soper as chairman and replace him with William B. Bell.

28. D. W. Reed to Cornelius Cadle, 12/8/1904, Ainsworth Collection; C. W. Kepler to John Hayes, 2/27/1905, Letterbooks, 9:351, Kepler Papers. Reed was the author of The Battle of Shiloh and the Organizations Engaged, which was originally published in 1902. On the work, see Timothy B. Smith's introduction to David W. Reed, The Battle of Shiloh and the Organizations Engaged (Knoxville, TN, 2008), xi-xxvii.

29. W. B. Allison to W. H. Taft, 9/29/1905 (copy), Allison Papers; J. W. Carson (commissioner for the 15th Iowa) to C. W. Kepler, 3/21/1906, Kepler Papers.

30. C. W. Kepler to G. W. Crosley, 2/27/1905, Letterbooks, 9:355, Kepler Papers; E. B. Soper to C. W. Kepler, 8/21/1906, Kepler Papers. 
As the Shiloh controversy unfolded, in April 1902 the General Assembly legislated into existence two additional commissions to erect monuments at Vicksburg and Chattanooga ${ }^{31}$ In making appointments to them, the newly elected governor, Albert Baird Cummins, leader of the of Iowa Republican Party's Progressive wing, had to balance the need to cultivate the support of the state's veterans (who generally were felt to be more sympathetic to the party's conservative - or Standpatter wing) and his followers' desire for patronage. He circulated lists of possible members to trusted political allies before making appointments. Although political conduct was a factor, so too were geographic distribution among the state's 11 congressional districts, prominence in the Grand Army of the Republic (GAR), and prior service on the earlier marking commissions. ${ }^{32}$

The Vicksburg commission was funded at the requested level of $\$ 150,000$ (the equivalent of roughly $\$ 3.5$ million in 2008). Five of its nine members had been on the marking commission. John F. Merry, who had not been, now successfully exerted himself to obtain a place on the monument commission and was elected chairman. Rigby's influence was rumored to be at work in arranging appointments to the commission, just as it had been in securing passage of the authorizing act and appropriation. ${ }^{33}$

Overall, the Vicksburg commission stood out from the others by virtue of the political prominence of its members: four commissioners - L. C. Blanchard, J. A. Fitchpatrick, E. J. C. Bealer,

31. Acts and Resolutions of the Twenty-Ninth General Assembly (Des Moines, 1902), chaps. 197-98; "Speeches Made in the Iowa House of Representatives, March 18, 1902, on the Passage of House File No. 155, A Bill for an Act Providing for the Erection of Monuments and Tablets on the Vicksburg National Military Park ..." pamphlet in Vicksburg Monuments file, GAR Collection, SHSI-DM.

32. See, for example, the following correspondence, all in Cummins Papers; S. X. Way to A. B. Cummins, 3/25/1902; H. J. Wilson to Cummins, 3/30/1902; G. M. Curtis to Cummins, 5/9/1902; F. Y. Locke to Cummins, 5/14/1902. On the political context, see Ralph Mills Sayre, "Albert Baird Cummins and the Progressive Movement in Iowa" (Ph.D. diss., Columbia University, 1958), chap. 7.

33. Acts and Resolutions of the 29th General Assembly, chap. 197; The Inflation Calculator at www.westegg.com/inflation/infl.cgi; J. F. Merry to Alonzo Abernethy, 3/4/1902, 4/2/1902, Abernethy Papers; Des Moines Daily Leader, 5/22/ 1902; J. K. P. Thompson to Alonzo Abernethy, 2/17/1902, Abernethy Papers. Merry was in Washington in early April 1902, successfully lobbying federal officials for a naval monument at Vicksburg. 
and W. O. Mitchell (a former Speaker of the House) - were current or former members of the General Assembly. Others also had demonstrable political connections. ${ }^{34}$ Although the Vicksburg commission's nine members each came from different congressional districts, it was less representative of the 32 commands that participated in the siege, as the nine members were drawn from but seven regiments. None of them came from the 15th Corps, a point that drew immediate and continued criticism. ${ }^{35}$

The 11-member Lookout Mountain and Missionary Ridge (hereafter LMMR) commission was authorized \$35,000 for three monuments, $\$ 10,000$ more than the marking commission had recommended. The commission's members, who had extensive experience on previous marking commissions, chose state senator John A. Young of Washington as chairman. The legislation authorizing the commission was unique in calling for one member to serve as superintendent of construction. That task fell to Solomon B. Humbert of Cedar Falls. ${ }^{36}$

Once appointed, the commissioners went about their work. In October the Vicksburg commission visited Arlington, Richmond, and Gettysburg on a trip to the GAR national encampment in Washington. The following July, Merry and two other members visited New York City, where they were entertained by Stuyvesant Fish, president of the Illinois Central Railroad, General Grenville Dodge, and General Oliver O. Howard before proceeding on to Boston to meet with sculptor Henry H. Kitson and other artists. Dodge enjoyed an almost Olympian reputation among the state's veterans and was no stranger to commemora-

34. David A. Haggard of Algona, for example, was a member of one of the most politically active families in the Tenth Congressional District, and Henry H. Rood of Mount Vernon was a former Republican presidential elector and national convention delegate who was often mentioned as a possible candidate for various offices. S. X. Way to A. B. Cummins, 3/28/1902, Cummins Papers; Biographical Dictionary of Linn County, Iowa (Chicago, 1901), 614-19.

35. J. D. Fegan to Alonzo Abernethy, 4/2/1902, Abernethy Papers; M. P. Smith to A. B. Cummins, 4/11/1907, Cummins Papers.

36. Acts and Resolutions of the Twenty-Ninth General Assembly, chap. 198; A. B. Cummins to Alonzo Abernethy, 6/7/1902, Abernethy Papers. Nine of the commission's 11 members had been members of either the Chattanooga or Vicksburg marking commissions. 


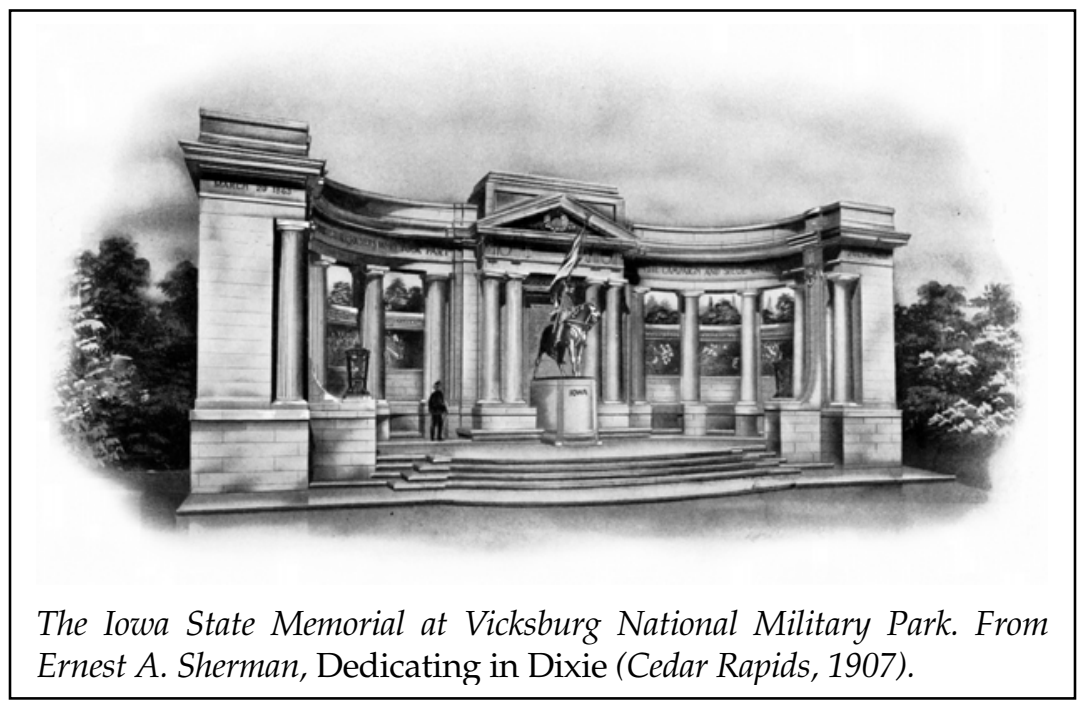

tive projects. He and Howard were strong advocates of Kitson's work, so it is not surprising that his design was selected. ${ }^{37}$

Kitson, who would be assisted by his wife, Theo Alice Ruggles Kitson, and architect Guy Lowell, designed a semi-elliptical exedra with six bronze relief panels depicting Iowa soldiers and sailors in heroic action in various phases of the Vicksburg campaign. At the center of the ellipse was a large statue of a soldier on horseback holding the national colors. ${ }^{38}$ Kitson promised "the very best work that can be procured for 100,000 dollars," and the Kitsons kept in close touch with Rigby as well as with the commission as they proceeded. ${ }^{39}$

37. Des Moines Daily News, 10/13/1902; Waterloo Daily Courier, 7/13/1903; O. O. Howard to J. A. Young, 1/27/1903 (copy), Abernethy Papers. Dodge served on six monument commissions, including those of Grant's Tomb in New York, the Grant monument in Washington, and the Sherman monument in Washington. Waterloo Daily Courier, 7/13/1903.

38. See the Smithsonian-IAS description at http://siris-artinventories.si.edu; and Panhorst, "Lest We Forget," 123-25. On the Kitsons generally, see Kathryn Greenthal, Paula M. Kozol, and Jan Seidler Ramirez, American Figurative Sculpture in the Museum of Fine Arts, Boston (Boston, 1986), 300-306. The general concept of the state monument was reported to be the idea of H. H. Rood. Waterloo Daily Courier, 12/15/1906.

39. H. H. Kitson to W. T. Rigby, 12/23/1903, 2/2/1904, Rigby Papers. Rigby would later employ Theo Kitson on numerous commissions at Vicksburg, in- 
What little controversy there was within the Vicksburg commission focused on how best to expend the remaining $\$ 50,000$ of the appropriation. The commissioners decided where possible to combine regimental commemoration into brigade monuments, 13 of which were ordered from E. H. Prior of Postville, Iowa. A third category of 59 bronze markers were commissioned from the Gorham Company of Providence, Rhode Island, to mark regimental positions. ${ }^{4}$

Meanwhile, the LMMR commission visited Chattanooga in November 1902 and decided that one monument should be erected on Lookout Mountain and two on Missionary Ridge. ${ }^{41}$ Originally the commissioners had planned to divide the appropriation equally among the three monuments, but Generals Howard and Dodge persuaded the commission that the bulk of the funds should be spent on one "immortal" work of art at "the most sightly place." Meeting at Cedar Falls in February 1903, the commission selected the designs of the Van Amringe Granite Company of Boston, with the largest monument to be at Rossville Gap, near the southern end of Missionary Ridge. ${ }^{42}$

The company went to work swiftly, quarrying and finishing granite, and eventually preparing inscriptions. ${ }^{43}$ The latter, of course, had to be approved by the federal commissioners of the Chickamauga-Chattanooga park and the secretary of war. Although nothing on the scale of the "second battle of Shiloh"

cluding statues of Stephen D. Lee, Jefferson Davis, and Samuel Jordan Kirkwood. See Panhorst, "Lest We Forget," 126-29. She is perhaps best known, though, for her archetypical Spanish-American War soldier, "the Hiker," which was widely reproduced.

40. E. J. C. Beeler to Alonzo Abernethy, 3/24/1903, Abernethy Papers; Alonzo Abernethy to W. T. Rigby, 9/16/1903 (copy), ibid.; H. H. Rood to W. T. Rigby, 4/11/1905, Rigby Papers.

41. Notes by Alonzo Abernethy, 11/5-11/10/1902, Abernethy Papers. The sites on Missionary Ridge provoked some disagreement, but a clear majority favored one at the north end at Sherman Heights and one at the south end.

42. O. O. Howard to John A. Young, 1/27/1903 (copy), Abernethy Papers; J. D. Fegan to Alonzo Abernethy, 1/27/1903, ibid; Minutes, 2/19-2/20/1903, ibid. William B. Van Amringe had gone to considerable pains to ascertain the commissioners' desires. Earlier in the month, he had visited Iowa and met individually with Abernethy, Young, and Humbert. Cedar Rapids Evening Gazette, 2/21/1903.

43. See Van Amringe's lengthy correspondence with Abernethy during 1903-5, Abernethy Papers. 
erupted, H. V. Boynton, head of the park commission, did require a number of changes that illustrate the extent to which federal rules could constrain state commissions. The most substantive required the dropping of an inscription from the Sherman Heights monument that would have recognized the contributions of Iowa's women to the war effort. That, Boynton explained - while a noble sentiment - fell outside the park regulation that required all inscriptions to be related to the battles of Chickamauga or Chattanooga. ${ }^{44}$

Commissioner Humbert departed for Chattanooga in December 1903 to supervise construction, with the goal of having the monuments ready for dedication in November 1904. He would eventually spend 189 days on site dealing with a variety of problems, beginning with the unsatisfactory performance of the local contractor Van Amringe hired to erect the monument. The largest monument, at Rossville Gap, proved the greatest challenge. Van Amringe sent successive granite shafts, 72 feet high - in contrast to the 50-foot height of the other two each of which sustained serious damage. At another point the construction crane came crashing down. Finally, a third shaft was successfully raised, although by that time the dedication had necessarily been postponed. ${ }^{45}$

44. H. V. Boynton to Alonzo Abernethy, 7/14/1903, ibid. The intended inscription would have read, "In memory of the brave women of Iowa who met their country's call by offering on the altar of freedom their prayers, their hearts, and their honor." E. B. Bascom to Alonzo Abernethy, 5/19/1903, ibid. It was replaced with the badge of the 15th Army Corps. Other changes were required in the inscriptions on the Rossville Gap monument, including eliminating the phrase "in a holy cause" and Lincoln's "malice towards none" passage from the Second Inaugural. H. V. Boynton to Abernethy, 9/3/1903, 9/15/1903, and Abernethy to Boynton, 9/16/1903, 9/12/1903 (copies), ibid. Boynton also ruled that although a quotation from Iowa's wartime governor Kirkwood (supplied by Benjamin F. Shambaugh) was appropriate, Kirkwood's name would have to be left off the monument as he was not involved in the battle. B. F. Shambaugh to Abernethy, 4/5/1903, ibid; H. V. Boynton to Abernethy, 9/3/1903, ibid.

45. S. B. Humbert to Alonzo Abernethy, 12/1/1903, 12/16/1903, ibid.; Humbert's and Van Amringe's letters to Abernethy, January-April 1904, ibid.; Humbert's letters to Alonzo Abernethy, April-July 1904, ibid.; J. A. Young to Alonzo Abernethy, 12/27/1905, ibid. All three Chattanooga monuments have outline maps of Iowa carved on the base and are topped with figures of color bearers. The Rossville Gap monument has four soldier figures around the base. For fuller descriptions of the Chattanooga monuments, see SI-IAS, http:/ / siris-artinventories.si.edu. 


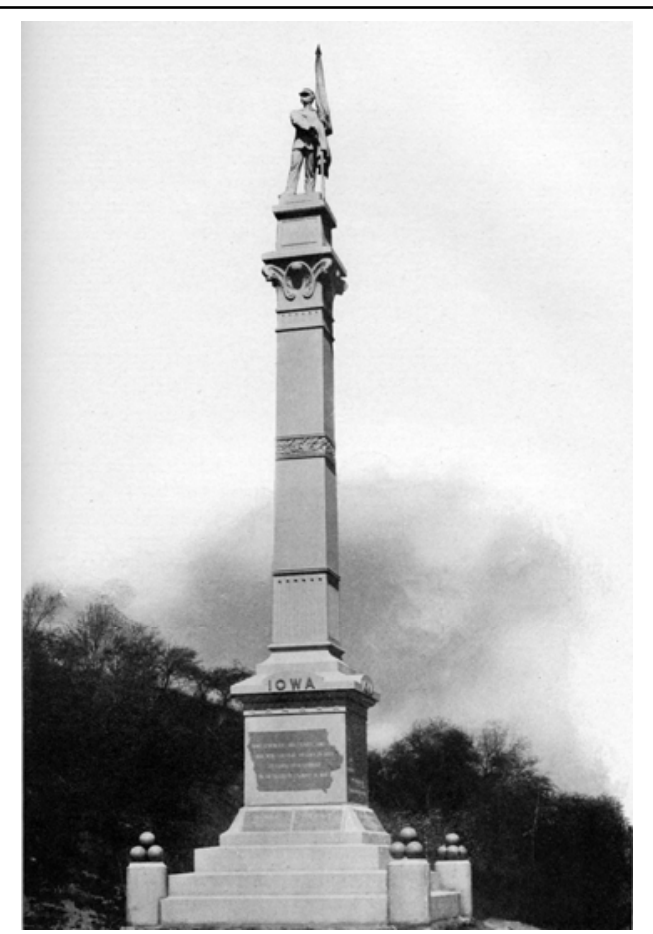

This monument at Lookout Mountain is typical of those at Chattanooga. Photo from Alonzo Abernethy, comp., Dedication of Monuments Erected by the State of Iowa (1908).
By that time, too, a fourth commemorative locus had emerged: the site of the notorious prisoner-of-war camp at Andersonville, Georgia. Although it was not a military park, the national Union Ex-Prisoners of War Association and its state-level affiliates successfully encouraged states to raise monuments to those who died there, either at the camp site (controlled by the National Woman's Relief Corps) or in the adjacent national cemetery. By 1904, five states had erected monuments at Andersonville, and five others had selected sites there. The Iowa Association of Ex-Union Prisoners of War had joined the campaign, and in April 1904 their efforts bore fruit as the Thirtieth General Assembly unanimously authorized the appointment of a five-member monument commission and appropriated $\$ 10,000$ for a monument. ${ }^{46}$

46. Iowa Ex-Union Prisoners of War Association, "Andersonville Monument Bill" [printed flyer], Andersonville Monuments file, GAR Collection; Iowa ExUnion Prisoners of War Association: What It Has Done and Is Doing [1904], ibid.; Acts and Resolutions of the Thirtieth General Assembly, chap. 166. The bill was drafted by Daniel C. Bishard, secretary of the Iowa ex-prisoners association, and modeled on one enacted in Ohio. Cedar Rapids Evening Gazette, 1/23/1904. On the history of the Andersonville site after the war, see Robert Scott Davis, "'Near Andersonville': An Historical Note on Civil War Legend and Reality," Journal of African American History 92 (2007), 96-105. 
Governor Cummins again consulted political advisors before making appointments to the Andersonville commission. ${ }^{47}$ The most noticeable thing about the appointments was that all three of the ex-prisoners association's officers were named, although only D. C. Bishard, its secretary, had been a prisoner at Andersonville. $^{48}$ The commissioners visited Andersonville in October 1904 and selected a site within the national cemetery. By early 1905, they had submitted their design and inscription to the U.S. quartermaster-general for approval. They contracted with the Des Moines Marble and Mantel

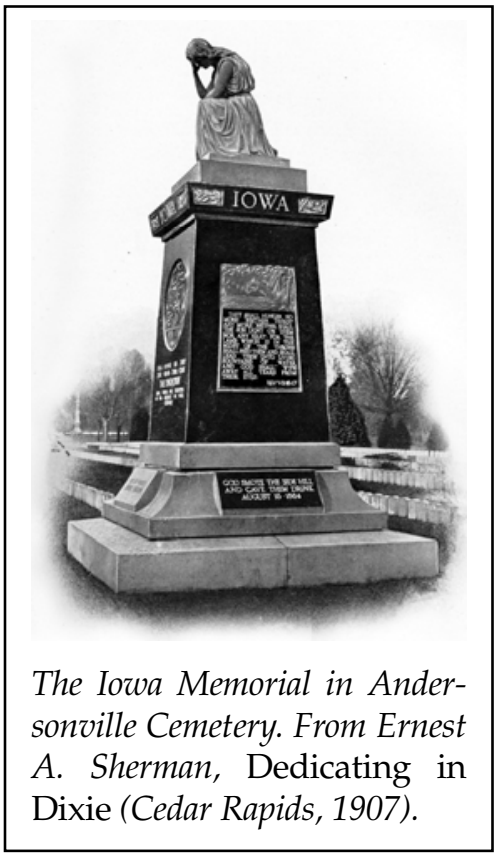
Company for a suitably funereal monument, based on a Thomas Nast drawing that featured a kneeling, weeping woman. ${ }^{49}$

BY THE BEGINNING OF 1906, Iowa's monuments were either completed or nearly so, except for the state monument at

47. See, for example, the following correspondence in the Cummins Papers: G. C. Scott to A. B. Cummins, 5/28/1904; Wade Kirkpatrick to Cummins, 5/31/ 1904; W. S. Hart to Cummins, 6/2/1904; H. M. Wilson to Cummins, 6/11/1904; D. C. Glasser to Cummins, 6/28/1904; W. G. Kerr to Cummins, 7/2/1904; and T. L. Green to Cummins, 7/21/1904.

48. Cedar Rapids Evening Gazette, 7/5/1904. The bill passed by the House had stipulated that the commission be filled only by those imprisoned at Andersonville, but the Senate amended it to require only that the commissioners had been prisoners in southern prisons. W. S. Hart to A. B. Cummins, 6/2/1904, Cummins Papers. The Iowa Ex-Union Prisoners of War Association had urged that its three officers be appointed. Cedar Falls Gazette, 7/15/1904. The Andersonville commission was the only one with members who had served in nonIowa regiments. Chairman James A. Brewer was a veteran of the 23rd Missouri, Milton T. Russell of the 51st Indiana, and W. C. Tompkins of the 12th U.S.

49. Oxford Mirror, 10/20/1904; D. C. Bishard to A. B. Cummins, 1/5/1905, Cummins Papers. For the design, see Smithsonian-IAS, http://sirisartinventories.si.edu. The Des Moines Marble and Mantel Company had bid unsuccessfully on work at Shiloh and Chattanooga. 
Vicksburg. Confident that the Shiloh inscriptions controversy was nearing a satisfactory conclusion, in January 1906 Governor Cummins proposed a combined tour to dedicate all of the monuments. The commission chairmen met the following month and fleshed out the plan. They fixed the tour for November and determined the order for the visits: Vicksburg, Andersonville, Chattanooga, then Shiloh. In April the legislature appropriated $\$ 7,500$ for the tour. ${ }^{50}$

Such a combined tour was a novel idea. States normally dedicated monuments as they were completed. ${ }^{51}$ A number of factors may have made a combined dedication tour desirable to the governor and the members of the commissions. The commissioners regarded the results of their work as a source of pride for the state; photographs of the monuments completed to date were to be featured in the 1906 Iowa Official Register. ${ }^{52}$ A combined tour would arguably attract more attention than a series of scattered dedications. It might also be politically advantageous to the governor, for 1906 was an election year and Cummins intended to seek an unprecedented third consecutive term. ${ }^{53}$ Such visible association with the state's Civil War veterans - still an important group in Iowa politics - could only help, especially coming on the heels of Cummins's prominent role in the Shiloh controversy. William H. Michael, American

50. J. A. Brewer and J. A. Young to E. B. Soper, 1/30/1906 (copy), Kepler Papers; E. B. Soper to G. L. Godfrey, W. B. Bell, and G. W. Crosley, 3/1/1906 (copy), enclosed in Soper to C. W. Kepler, 3/2/1906, ibid.; Acts and Resolutions of the Thirty-first General Assembly (Des Moines, 1906), chap. 190. The Vicksburg commission had already decided on a November dedication, and river conditions at Shiloh would also be more favorable then. The latter was a significant factor because lack of adequate rail and road access meant that travel by steamboat would be necessary to get any large number of people to the Shiloh battlefield.

51. The neighboring state of Illinois, for example, dedicated its monuments at the same four sites in October 1906, December 1912, November 1899, and May 1904, respectively. Don Russell, "Illinois Monuments on Civil War Battlefields," Papers in Illinois History and Transactions for the Year 1941 (Springfield, 1943), 1-37. Compare also with the account of Indiana's battlefield monuments in Madison, "Civil War Memories and 'Pardnership Forgittin'," 209-19.

52. W. B. Martin (Secretary of State) to Alonzo Abernethy, 12/19/1905, Abernethy Papers.

53. On Cummins's decision to seek a third term, see Sayre, "Cummins," 332-39. Samuel J. Kirkwood had earlier served three terms, but the second and third had been separated by 12 years. 
consul in Calcutta and a veteran of the 15th Iowa, remarked, "While I am as a rule not in favor of three terms for either Governor or President, yet if I were in Iowa and a voter there, I would certainly take off my coat and work for Cummins. He is the kind of a man I like. .. . He did things for the soldiers of the 15th and 16th Iowa." ${ }^{54}$ Not all veterans, of course, rushed to support Cummins. Lot Abraham, an influential and active veteran who would later serve as GAR Departmental Commander, considered Cummins's bid for a third term "an outrage." ${ }^{55}$

Cummins's summer was dominated by a stiff challenge for the Republican nomination from George Perkins, followed by the fall campaign against Democrat Claude Porter, so much of the planning of the tour fell to John F. Merry. Given his considerable experience in commemorative activity and his position with the Illinois Central Railroad, he was the obvious choice. He worked out the itinerary and obtained reduced fares from the railroads. He also oversaw efforts to publicize the trip. A circular letter with the schedule of dedications and detailed instructions on purchasing tickets went out on September 28 over the names of the four chairmen to every GAR post in the state. The letter exhorted members to "participate in the solemn but patriotic and ever-to-be-remembered exercises." The press also publicized the upcoming tour in communities large and small. ${ }^{56}$

The commissions now concentrated on planning their dedication ceremonies. The basic outline was well established. It focused on two basic transactions. The commissions would first turn their monuments over to the governor, who would then transfer them to a representative of the federal government. These actions were customarily embroidered with oratory, mu-

54. W. H. Michael to C. W. Kepler, 10/29/1906, Kepler Papers. John Hayes, secretary of the Shiloh commission, pledged his support to Cummins soon after the latter announced that he would run for a third term. Hayes to Cummins, 2/17/1906, Cummins Papers.

55. Diary, 1906-7, Lot Abraham Papers, UI-SC. A lifelong Republican, Abraham eventually worked in the general election for Claude Porter, "a very respectable man for a Democrat." Abraham, who had attended the dedication of the Chickamauga-Chattanooga park in 1895, did not participate in the 1906 tour.

56. J. F. Merry to "My Dear Will" [W. T. Rigby], 8/3/1906, Rigby Papers; “Dedication of Iowa Monuments on Southern Battlefields" [printed flyer], Kepler Papers; Fredericksburg News, 9/27/1906; Des Moines Daily News, 10/7/1906; Cedar Rapids Weekly Gazette, 10/11/1906. 
sic, and other festivities. As a symbol of sectional reconciliation, it was common for a Confederate veteran to speak. ${ }^{57}$

Again, the Iowa commissions showed their individuality. For Vicksburg, Merry left the details in Rigby's capable hands, even asking for advice on his own remarks. ${ }^{58}$ The proceedings there would prove the most elaborate. Rigby secured Grenville Dodge to accept the monuments for the federal government. ${ }^{59}$ A poem was commissioned from S. H. M. Byers, arguably the state's best-known poet. ${ }^{60}$ By the end of October, the Vicksburg commission had produced a lavish program that was the envy of other commissions. ${ }^{61}$ The Shiloh commission, the extended controversy over the inscriptions on the 15th and 16th Iowa monuments fresh in mind, decided to have two days of dedications, with one given over to the 11 regimental monuments. ${ }^{62}$ The LMMR commission was late in getting out its invitations and in contacting the local United Confederate Veterans (UCV) commander for help in finding a group of schoolchildren to sing. Its program, which was the plainest of the group, went to press with a blank space for the name of the official who would accept the monuments for the federal government. ${ }^{63}$

57. See Panhorst, "Lest We Forget," 66-68.

58. J. F. Merry to W. T. Rigby, 8/3/1906, Rigby Papers.

59. H. H. Rood to W. T. Rigby, 4/6/1906, with endorsements by Rigby (4/13/ 1906), F. C. Ainsworth (4/18/1906), and Robert Shaw Oliver (4/19/1906), Grenville Dodge Papers, SHSI-DM.

60. Byers was paid $\$ 100$ for the poem. "Expenses Other than Members," Kepler Papers. On Byers, see "S. H. M. Byers," Palimpsest 13 (1932), 429-72. Byers was best known for "Sherman's March to the Sea," which he wrote while in a Confederate prison and successfully had smuggled out in another prisoner's wooden leg. He also wrote "The Song of Iowa."

61. J. A. Young to Alonzo Abernethy, 11/1/1906, Abernethy Papers; G. W. Crosley to C. W. Kepler, 11/1/1906, Kepler Papers.

62. G. W. Crosley to C. W. Kepler, 10/1/1906, Kepler Papers. Crosley had studied the programs from the Illinois, Ohio, Indiana, and Wisconsin dedications and noted that none of them had dedicated regimental monuments individually, "but I know our people expect these ... and I am anxious to have them."

63. L. T. Dickinson to Alonzo Abernethy, 10/5/1906, Abernethy Papers; Program, Chattanooga Monuments file, GAR Collection. It had originally been thought that Dodge would also accept the monuments at Chattanooga, but he had decided to leave the tour after it reached Atlanta and proceed to Washington to deal with problems that had arisen with the Grant monument there. See Dodge Biographical Record, 19:475-79, Grenville Dodge Papers. 


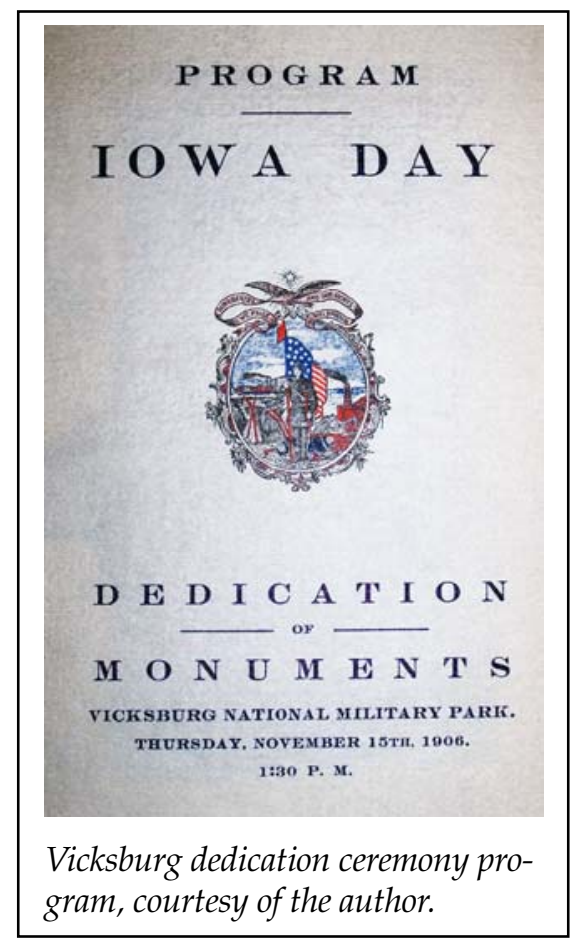

The governor's party and many of the tour's members boarded the "Governor's Special" in Des Moines on the evening of November 12. Others joined them en route or in Chicago, and at ten the next morning the combined train - "the finest train that ever left Iowa" according to Charles Kepler — headed south on the Illinois Central line. ${ }^{64}$ On the train were approximately 160 participants. They included Governor and Mrs. Cummins, the governor's military staff, various officials and officeholders, a stenographer, members of the state legislature, all but two members of the four monument commissions (some with family members), the 55th regimental band (a national guard unit from Centerville), the state GAR commander, numerous veterans and their guests, and other interested parties. ${ }^{65}$

64. C. W. Kepler to Mrs. C. M. Finch, 3/11/1906, Letterbooks, 12:330, Kepler Papers.

65. There are two lists of tour participants: Ernest A. Sherman, Dedicating in Dixie (Cedar Rapids, 1907), 5-9, which lists 160; and Dedication of Monuments 
The governor's guests included Frederick M. Hubbell, said to be the richest man in Iowa. ${ }^{66}$ The governor's party had its own sleeper, as did each of the four commissions, and Grenville Dodge came along in his private car.

A few of the participants would publish accounts of the tour. Among these was Ernest A. Sherman, a Cedar Rapids printer who published the Saturday Record. Upon return, he published a series of articles recounting experiences on the trip that he expanded and published in book form in 1907 as Dedicating in Dixie. ${ }^{67}$ This breezy, anecdotal account provides one of the major sources for the tour, along with the more official Dedication of Monuments Erected by the State of Iowa, compiled and edited by Alonzo Abernethy and published by the state in 1908. John M. Grimm also wrote an account of the tour for the Cedar Rapids Weekly Gazette. ${ }^{68}$

The train arrived behind schedule in Vicksburg on November 15, and was greeted warmly by "the booming of cannon

Erected by the State of Iowa, comp. Alonzo Abernethy (Des Moines, 1908), which lists 159. The two lists are nearly identical, but Sherman lists three people that Abernethy does not and the latter includes two that Sherman does not. Sherman also lists 12 individuals who were on the Special for part of the tour. The Des Moines Register and Leader also printed two shorter lists on 11/12/1906 and $11 / 26 / 1906$, as did the Paducah Evening Sun on 11/24/1906. The two commissioners who did not go were E. B. Soper and Milton T. Russell. The former, perhaps smarting from his deposition as Shiloh commission chairman, had decided not to go (Daniel Matson to C. W. Kepler, 10/23/1906, Kepler Papers); the latter, a member of the Andersonville commission, went instead to California to try to recover his health (Des Moines Register and Leader, 11/12/1906).

66. Diary, F. M. Hubbell Papers, SHSI-DM. On Hubbell, see William B. Friedricks, Investing in Iowa: The Life and Times of F. M. Hubbell (Des Moines, 2007); and George S. Mills, The Little Man with the Long Shadow: The Life and Times of Frederick M. Hubbell (Ames, 1988). Hubbell was not a veteran. Although of military age, he had not served during the war. Unlike most of the tour participants, he was a Democrat. He likely came along out of his friendship with Cummins, whose legal client he had often been. Both were members of "the Owls," an informal poker club that met regularly in Des Moines. He also had a connection with the tour through his younger son, who had married the daughter of G. L. Godfrey of the Shiloh monument commission.

67. Sherman's firm did printing for veterans' organizations, especially Crocker's Iowa Brigade Association, and printed the programs for the Vicksburg dedication. "Expenses Other than Members," Kepler Papers.

68. Cedar Rapids Weekly Gazette, 12/5/1906. Grimm was the son-in-law of E. J. C. Beeler, a member of the Vicksburg commission. On Grimm, see Biographical Dictionary of Linn County, 739-40. 
[and] by pretty nearly everything in the shape of a vehicle that Vicksburg could produce." On arrival, the tourists were taken to the national cemetery and battlefield park, where they viewed some of the monuments already erected. The just-dedicated Illinois monument - a Pantheon-like white marble structure containing the names of 36,000 Illinoisans who had fought in the campaign - was especially impressive. F. M. Hubbell described it as the "most magnificent of its kind in the U. S." The evening featured a reception hosted by the mayor, which proved, Sherman noted, "a revelation to the Iowa party. They do not use water in their punch in Vicksburg." ${ }^{\prime 69}$ No other stop on the tour would match Vicksburg's festive welcome and hospitality.

The next day brought more touring, with dedication ceremonies beginning at the Iowa state monument at 1:30. The full slate of ceremonies took on a broadly reconciliationist character. Musical selections included "America," "Nearer, My God, To Thee," "Dixie" (twice, once by the 55th regimental band and once by a choir of Vicksburg schoolchildren), and "The StarSpangled Banner." The unfinished state monument itself was unveiled by Rigby's daughter and three other young Vicksburg women. In his speech, Governor Cummins reminded the audience, estimated at some 2,500, that "the war of 1861 was fought, not to determine the status of the negro, but to establish the permanence of the Union." The Iowa monuments were intended "to commemorate ... the courage and heroism of Iowa soldiers," just as other monuments would be raised to the courage of Confederate soldiers. Dodge accepted the monuments for the government in a long speech that focused on the Vicksburg campaign itself. Mississippi governor James K. Vardaman followed with a speech that continued the theme of reconciliation. The real difference in the American people, he remarked, was not between North and South but between those "who inhabit the great cities and the people who dwell in the country." It was among the latter that "about all the patriotism we have now is found."

69. Sherman, Dedicating in Dixie, 25-27; Abernethy, Dedication of Monuments, 25-26; Hubbell Diary, 11/14/1906, 11/15/1906.

70. For the text of the speeches, see Abernethy, Dedication of Monuments, 27-72. This can be supplemented by Sherman, Dedicating in Dixie, 19-21. Sherman noted that by the time Dodge finished, the crowd was beginning to thin. Many 
Charles A. Clark, Iowa GAR commander, gave the main address. A veteran of the 6th Maine who had not been at Vicksburg, he focused more on the overall character of the war, going through the various names given it and rejecting "War of the Rebellion," "Civil War," and "War Between the States" as in different ways inadequate. It should, he reasoned, be called the "War for the Union." Slavery had had to be destroyed because it had become a threat to the Union. The Union soldier "and his no less gallant adversary gave us the heroic era of American history to which future generations will look back as their most glorious heritage." By the time S. H. M. Byers rose to read his 40-stanza poem "Vicksburg," it was nearly twilight, and the crowd had diminished considerably. Hubbell concluded that the exercises had been "very impressive"; they were certainly the most expensive of the tour. ${ }^{71}$

From Vicksburg, the Governor's Special set out for Andersonville. Pulled on that leg of the trip by an underpowered engine, the train reached its destination a day late. ${ }^{72}$ The ceremony took place at 10:30 after a solemn procession from the train to the national cemetery. The quasi-religious mood was in sharp contrast to the festivities of Vicksburg and evoked few references to regional reconciliation. There was, for one thing, no local welcome or local participation in the ceremonies. This was clearly a federal installation, and the honor guard was provided by a detachment of the 17th U.S. Infantry from Fort McPherson in Atlanta.

Cummins's speech at Andersonville began by noting that it was much more difficult to speak at the site of the prison, with its sad and bitter memories, than it had been at Vicksburg. He interwove excerpts from "The Battle Hymn of the Republic" with themes from Lincoln's Gettysburg Address and Second Inaugural. The sin that the United States had committed was

were relieved that Vardaman had not repeated the combative tone he had employed at the Illinois dedication the month before. See Waldrep, Vicksburg's Long Shadow, 179-80.

71. Hubbell Diary, 11/15/1906. The expenses for the Vicksburg dedication (\$1089.50) surpassed those of the other three dedications combined (\$866.51). "Expenses Other than Members," Kepler Papers.

72. Hubbell Diary, 11/15/1906, 11/16/1906. 
expiated here, in the suffering of Union prisoners. But their truth, like God's, was marching on, and embodied in the flag that "flies for all her citizens, without respect to condition in life, whether they be high or low, rich or poor, white or black." ${ }^{73}$ Hubbell remarked that the speech was "very beautiful," and it was generally judged the most impressive of the tour. ${ }^{74}$

After Mrs. Cummins unveiled the monument, Gen. Ezra A. Carman, a New Jersey veteran who had the year before succeeded Boynton as head of the Chickamauga-Chattanooga park commission, accepted it on behalf of the United States. His speech also paid tribute to the sacrifices and fortitude of the Union prisoners and noted the cruelty of the conditions. However, he also told the audience that the federal government was "measurably guilty also" for the suffering because it was a party to ending the exchange of prisoners in order to shorten the war. Now, 40 years later, Americans had reconciled to produce "a true union on the lines of mutual respect, brotherly love, and a united patriotism." That afternoon, the party visited the site of the adjoining prison, and the 55th's band provided a concert of sacred music that seemed appropriate to the occasion. Dodge noted that "I saw no one who was not really in tears," but all was not solemnity. Daniel Matson of the Shiloh commission and two other tourists arranged, as Sherman put it, "a genuine darkey banquet of corn pone, 'lasses, and kindred eatables" in a cabin near the depot, which was followed by "a genuine darkey hoe-down." ${ }^{75}$

73. Abernethy, Dedication of Monuments, 98-101. For a rhetorical analysis of the speech, see Elbert W. Harrington, "The Public Speaking Career of Albert B. Cummins" (Ph.D. diss., University of Iowa, 1938), 159-60; and idem, "Albert Baird Cummins as a Public Speaker," Iowa Journal of History and Politics 43 (1945), 235-36.

74. Hubbell Diary, 11/17/1906. John M. Grimm characterized the speech as "one of his very best speeches," and Sherman also extolled it as "the most beautiful, the most touching, the most eloquent address of the tour" (56). The following year it was printed in the Annals of Iowa 8 (1907), 139-42. The acting governor of the Alaska Territory, who had been a prisoner at Andersonville, wrote to Cummins, asking for a copy. W. L. Distin to A. B. Cummins, 4/5/ 1907, Cummins Papers.

75. Abernethy, Dedication of Monuments, 102-7; Dodge to Fr. T. E. Sherman, 11/21/1906, Grenville Dodge Papers; Dodge Biographical Record, 19:405-6, ibid.; Dedicating in Dixie, 128-29. Matson represented the 14th Iowa on the Shiloh commission; he also served in the 4th U. S. Heavy Artillery (Colored). 
In the early evening, the Special departed for Atlanta, now a full day behind schedule, arriving at 2:10 a.m. on Sunday, November 18 . The late arrival had necessitated canceling a Saturday noon luncheon and an evening reception at the governor's mansion. Cummins spent the day receiving visitors at the Piedmont Hotel and gave an interview to the Atlanta Constitution. The tourists saw what remained of the battlefields around the city. Some went to a fashionable local church, where, according to Sherman, they had a "rather chilly experience." That evening a few went to an African Methodist Episcopal church, where they were warmly welcomed. Cummins declined an offer from Georgia officials to waive a state law prohibiting excursion trains from running on Sundays, saying that as governor of one state he would not violate the laws of another. The Special did not depart for Chattanooga until after midnight. ${ }^{76}$

The Special arrived in Chattanooga just in time for the tourists to disembark and ascend Lookout Mountain by means of an incline railway for the first of the three Chattanooga dedications. The weather was foggy and raw, much like the day of the battle 43 years earlier, and some stayed on the train. Those who went found themselves deposited at the top of the mountain, and had to descend some 800 wet steps down to Craven Terrace, the actual location of the battle and monument. The fog eventually cleared, allowing them to admire the impressive view. ${ }^{77}$

The dedication services on Lookout Mountain began with a long invocation, seeking blessings on the president, the armed forces, the veterans, and the permanency of the Union. Alonzo Abernethy, secretary of the LMMR commission, gave the most noteworthy of the speeches. An accomplished amateur historian, Abernethy sought to place the war and its commemoration in a historical context that identified the American experience with the "cause of humanity." The American Revolution had established the principle that governments derived their powers from the consent of the governed, but it had taken the Civil

76. Atlanta Constitution, 11/16/1906, 11/19/1906; Sherman, Dedicating in Dixie, 129 (quotation); Hubbell Diary, 11/18/1906; John Hayes to C. W. Kepler, 12/11/1906, Kepler Papers.

77. Sherman, Dedicating in Dixie, 89; Abernethy, Dedication of Monuments, 133; Hubbell Diary, 11/19/1906; Cedar Rapids Weekly Gazette, 12/5/1906. 
War not only "to save the old Union on the old basis," but also to teach that "a free people cannot permit any part or class of their number to suffer oppression or wrong." In the wake of the Spanish-American War, it was unlikely that any nation could challenge American power externally; the new challenges were internal. Only "alert and honest manhood" in the spirit of 1776, 1861, and 1898 could "stem the tide of American industrial ambition and greed for wealth and power, the portending menace of our time." That was the ultimate purpose and value of monuments. By commemorating the heroic and selfless service of the past, they would inspire the same "spirit of unselfish devotion and lofty manhood" that would culminate in a "fourth and superb expression of the brotherhood of man, preparing our country for its greater mission, at home and abroad."

The Iowa party made its way back into Chattanooga and up to the northern end of Missionary Ridge for the afternoon dedication of the monument at Sherman Heights. One of the speakers there, Mahlon Head, commissioner for the 10th Iowa, stressed the need to prevent future wars. He also acknowledged the contributions of the Iowa home front and expressed gratitude for the state's treatment of its soldiers during the war. In his concluding address, the governor reminded his audience that the war had not settled "all things relating to the Republic," as speakers often maintained. He gave this a Progressive twist: "The age of experiment in free institutions has not passed."

The next day's activities focused on the dedication of the largest of the Iowa monuments, at Rossville Gap, in the most elaborate of the Chattanooga ceremonies. The Chattanooga GAR post turned out en masse, as did the local United Confederate Veterans camp. Chattanooga Mayor W. L. Frierson offered a suitably reconciliationist welcome to the "holy ground" of Missionary Ridge. LMMR commission chairman John A. Young

78. Abernethy, Dedication of Monuments, 137-48. Also speaking were General James B. Weaver, whose remarks addressed the battle itself, and Henry A. Chalmers, a Confederate veteran. Both took reconciliationist themes. Governor Cummins's concluding remarks were brief, but picked up on the Progressive themes that Abernethy had raised.

79. Abernethy, Dedication of Monuments, 151-52. Other speakers at Sherman Heights were State Senator Nathan Kendall and Captain J. P. Smartt, a Confederate veteran from Chattanooga. 
formally presented all three of the monuments to the state. The war's causes, he said, mattered less than the war itself, which was unique in "the magnitude of its operations ... the courage of the men composing the armies, and the far-reaching consequences of its termination." The two armies were equally brave, according to Young, but the North's view of the Union's perpetuity was right and had now been vindicated by the service of Tennesseans, Georgians, and Iowans together in the war against Spain. $^{80}$

Governor Cummins, accepting the monuments, focused on the gratitude due the common soldiers of the war, too often overlooked in the emphasis on commanders. The American citizensoldier had earned a place alongside the heroes of the ancient world and those of England who had defeated Napoleon to ensure that "the freedom of the Anglo-Saxon should not perish from the earth." General Carman, accepting for the federal government, joined Young in dismissing the causes of the war as less important than its results, and pointed to the growth of the country in general and the South in particular as evidence of the benefits of Union victory. The monuments would inspire generations to come: "These monuments of manhood, brave and high,/Do more than forts or battleships to keep/Our dearbought liberty." ${ }^{\prime 1}$

The tour departed Chattanooga at 9:30 p.m. for Johnsonville, Tennessee, where the next morning, November 21, the tourists disembarked before breakfast to meet the two riverboats that would take them 116 miles up the Tennessee River to Pittsburg Landing and the Shiloh battlefield. It was 3:00 a.m. the following morning before the second of the boats arrived at Pittsburg Landing. Some veterans made their way to Johnsonville on their own to catch the boat to Shiloh. ${ }^{82}$

80. Abernethy, Dedication of Monuments, 161-71; Chattanooga Times, 11/21/1906. The Rossville Gap monument is actually located just south of the state line, in Rossville, Georgia.

81. Abernethy, Dedication of Monuments, 182. The (unattributed) lines quoted are from Henry Van Dyke's "National Monuments."

82. See, for example, Robert Garden, History of Scott Township, Mahaska County, Iowa; War Reminiscences; Did the Buffalo Ever Inhabit Iowa? (Oskaloosa, 1907), 197-295. Garden and J. D. McGarraugh after missed connections and two changes of trains barely made it to Johnsonville in time to catch their boat. 


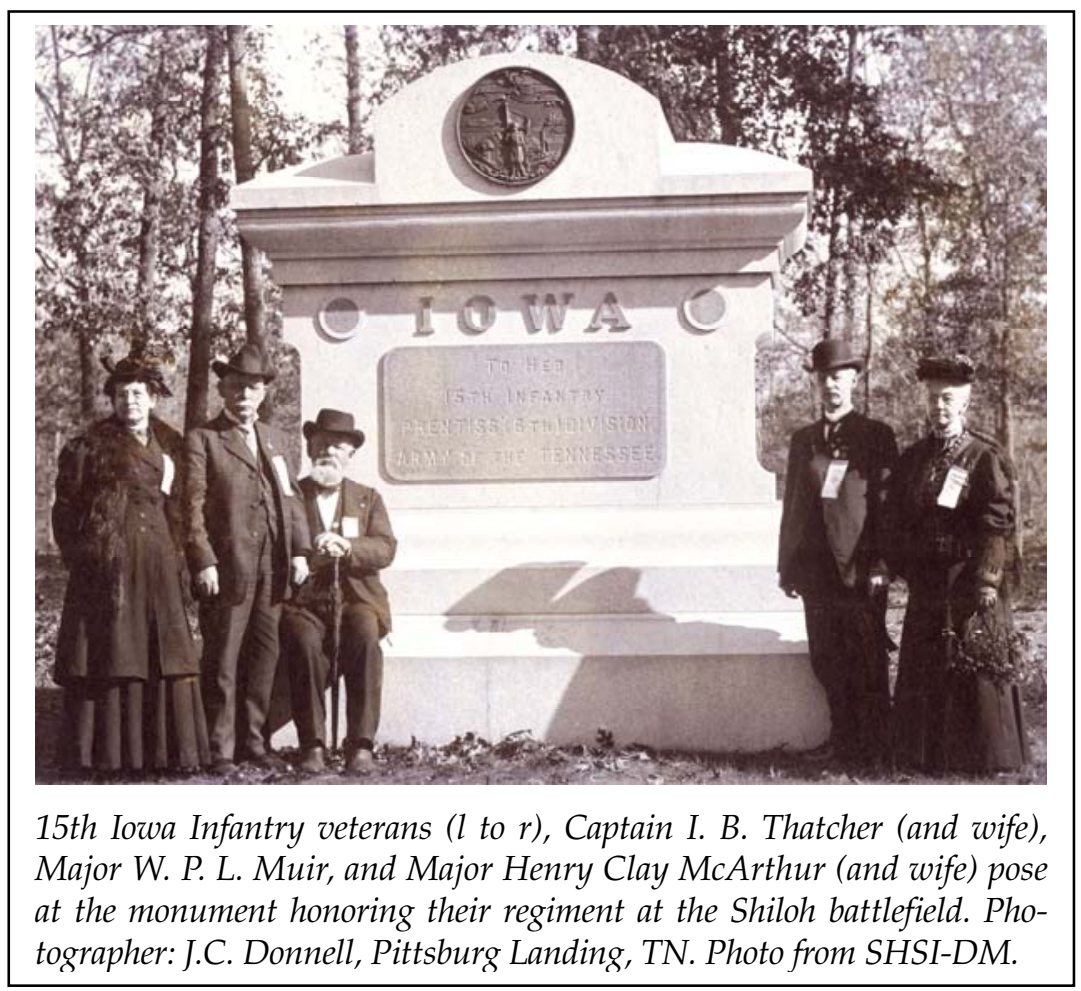

The Shiloh commission had decided that the first day at Shiloh would feature a series of dedications at the regimental monuments. At a meeting in Chattanooga, the commissioners decided to start with the 16th and 15th Iowa, the objects of the recent controversy. Ceremonies began at the 16th Iowa monument at 9:00 a.m. with John Hayes speaking. He did not allude to the controversy, although he placed the 16th at the scene in the morning of the battle's first day. At the next stop, however, H. C. McArthur, speaking for the 15th Iowa, made it clear that had the "exact truth" not been inscribed on the monument neither it nor the 16th's would have been dedicated. ${ }^{83}$

83. Abernethy, Dedication of Monuments, 207. McArthur had been one of the fiercest partisans in the controversy. There was concern that D. W. Reed and Cornelius Cadle, chairman of the federal park commission, might attempt to frustrate their plans, or at least reduce their impact. C. W. Kepler to W. B. Bell, 12/14/1906 (copy), Letterbooks, 13:1-5, Kepler Papers. Reed actually was of 
The party made its way along a five-mile arc from the Union right to the left. What would happen when the group reached the 12th Iowa monument, the third from the last, was uncertain. Not only had deposed chairman Soper refused to make the trip, he had sent word that he and a group of officers from the regiment had decided that no ceremonies should be held at the 12th's monument. The monument commission decided otherwise. Charles Kepler, in overall charge of planning the regimental dedications, confronted Reed early in the morning. "If ever I talked plain and to the point," wrote Kepler afterwards, "I did to him." After first refusing to have anything to do with the dedications, by the time the party reached the 12th's monument, Reed had changed his mind and informed Kepler that he would speak. "It is the only sensible thing you have said since this fight commenced," replied Kepler. ${ }^{84}$

At the last regimental monument, that of the 3rd Iowa, Governor Cummins extolled the work of the commission in creating the regimental monuments, which he felt got them "a little closer to the 'boys.'" The monuments were not only for those who had made the supreme sacrifice, but for all Iowans who had fought at Shiloh. ${ }^{85}$ Indeed, one is struck by the fact that except at Andersonville - the living veterans tended to get as much attention on the tour as the dead did.

The afternoon of the 23rd saw the dedication of the state monument and afforded the most concentrated barrage of oratory since the tour's first stop at Vicksburg. Chairman Bell summarized the trip to that point, briefly described the battle, and concluded with a short description of the commission's work in which he alluded to the delay in dedicating the monuments but not specifically to the inscriptions controversy. He then presented the monument to Governor Cummins. ${ }^{86}$

considerable help to Bell, arranging local transport and making contact with Governor Cox of Tennessee. Bell to G. W. Crosley, 10/4/1906, and Reed to Bell, 11/2/1906, Kepler Papers.

84. C. W. Kepler to J. H. Stibbs, 11/25/1906, Letterbooks, 12:394-97, Kepler Papers; C. W. Kepler to E. B. Soper, 11/26/1906, ibid., 12:402-4; C. W. Kepler to L. S. Tyler, 12/15/1906, ibid., 13:59-60.

85. Abernethy, Dedication of Monuments, 240-41.

86. Ibid., 243-49. 


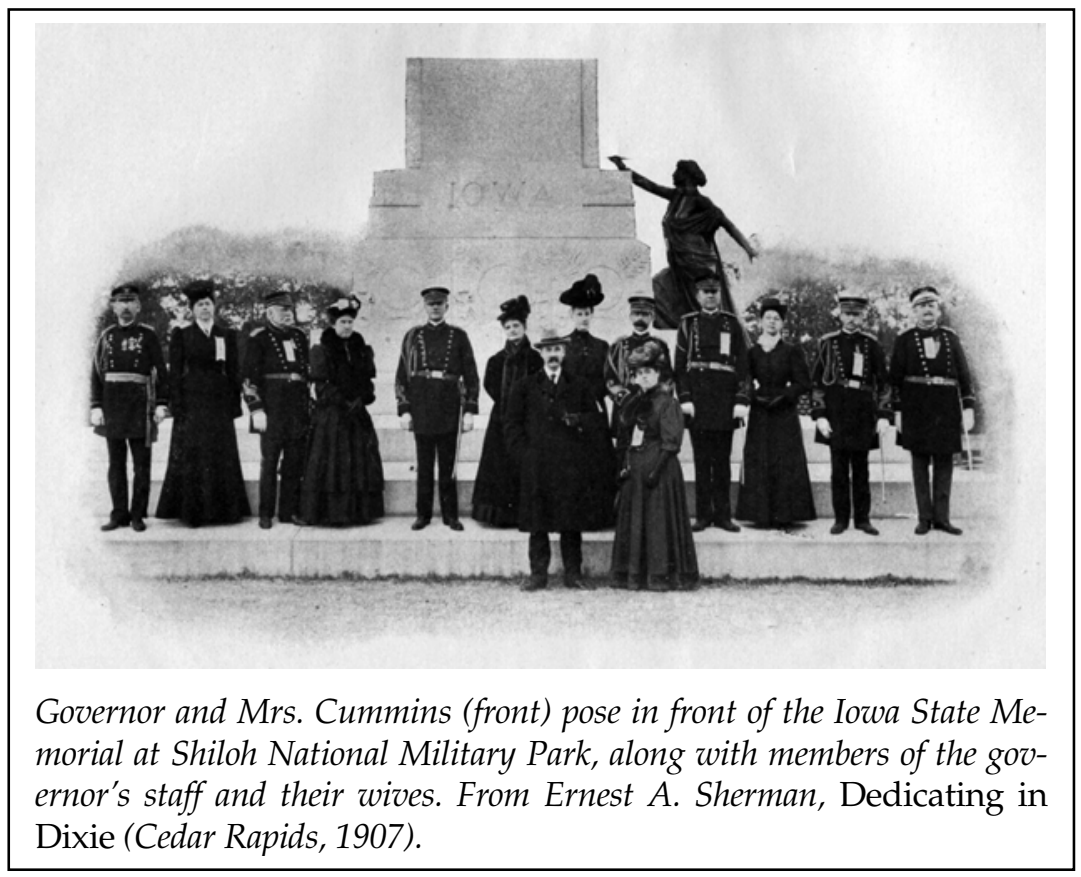

Cummins contrasted the calmness of the battlefield as they viewed it with the conflict of 44 years earlier and declared both sides "equally the heirs of a glory we never could have enjoyed if, in the end, the Union had not been triumphantly sustained." He declared the monument dedicated to "its high and holy purpose" that it might stand as "evidence of a high courage and patriotism never exceeded in the history of mankind." In accepting the monuments, Cornelius Cadle, chairman of the federal park commission, noted that when they had fought for the preservation of the Union, they had no idea that they were also helping to establish the United States as a world power. He recited the lines of S. H. M. Byers inscribed on the state monument and then provided a brief history of the battlefield park and federal commission. Noting that 110 monuments had so far been erected by the states at a cost of about $\$ 213,000$, he proclaimed Iowa's "the most artistic." ${ }^{87}$

87. Ibid., 249-55. Byers's lines ran: "Brave of the brave, the twice five thousand men/Who all the day stood in the battle's shock,/Fame holds them dear, and 
The next speaker was another member of the federal commission, Confederate veteran Basil Duke. The war, Duke said, had been "a terrible ordeal" but ultimately accomplished "much of good," removing "all misunderstanding, all sectional misconstruction and jealousy, and antagonism . . . from American life." The heroism of both sides was now "the common heritage of a reunited country." Never mentioning slavery or race (except in noting that the war was fought among "a people of the same blood"), it was a classic reconciliationist statement. ${ }^{88}$

The next speaker, General James B. Weaver, shocked the crowd. A former Republican congressman and Shiloh veteran, he had pursued an idiosyncratic political career that had seen him run for president as a Greenbacker (1880) and as a Populist (1892). He was now 73, mayor of Colfax, Iowa, and a Democrat. He started out conventionally enough, extolling the importance of Shiloh by comparing it to famous battles of antiquity. Affirming his belief in racial equality, he then asserted that there was no inconsistency between the equality of the races and the fact "this is a white man's government." The former slaves and their descendents had been treated shabbily. The only solution was for the federal government to take the lead in fostering an "exodus" of blacks to Africa. ${ }^{89}$

with immortal pen/Inscribes their name on the enduring rock." The $\$ 213,000$ cost of the monuments in 1906 is roughly equivalent to $\$ 5$ million today.

88. Ibid., 256-68. Like many supporters of New South economic development, Duke was an ardent reconciliationist. See Gary Robert Matthews, Basil Wilson Duke, CSA: The Right Man in the Right Place (Lexington, KY, 2005), 203-305. Sherman considered Duke's speech "one of the best and most patriotic addresses" of the tour. Dedicating in Dixie, 120. Duke was followed by W. K. Abernethy, representing the governor of Tennessee. The son of a Confederate veteran, Abernethy did list slavery among the issues settled by the war, and he assured the Iowans that their monuments and the graves of their soldiers would be lovingly maintained by Tennesseans.

89. Abernethy, Dedication of Monuments, 268-77. Weaver termed the country's policy towards African Americans "false, cruel, and unchristian." It had "liberated them and set them adrift without chart or compass." Emigration was the answer: "Let the whole Negro race in this country set their faces towards Africa and a Black Republic." For a rhetorical analysis of the speech, see Kenneth Gerhard Williams, "A Rhetorical Study of the Speechmaking of General James B. Weaver" (Ph. D. diss., Northwestern University, 1954), 417-35. On Weaver generally, see Fred Emory Haynes, James Baird Weaver (Iowa City, 1919); and Robert B. Mitchell, Skirmisher: The Life, Times, and Political Career of James B. 
Although earlier press reports had indicated that Weaver intended to address the "race question," the speech surprised many and created what the Des Moines Register and Leader termed "a profound sensation.." ${ }^{10}$ Some of the firsthand accounts of the tour ignored or downplayed the speech, but it attracted considerable press attention in Iowa. The Cedar Rapids Republican offered a generally positive evaluation of the speech, while the Register and Leader condemned it and provided a platform for rebuttals. ${ }^{91}$ Afterwards, George W. Crosley of the Shiloh monument commission commented that the speech had "met with so much unfavorable comment."

The other major oration of the day was given by Nathan E. Kendall, a rising star in Iowa politics and future governor, who steered well clear of the points Weaver had raised. Striking chords of Lincolnian rhetoric, he emphasized the unique importance and scale of the war. He then switched to the theme of Lincoln's Second Inaugural to explain the war as a punishment for the national sin of slavery, before praising the unified repub-

Weaver (Roseville, MN, 2008), who discusses Weaver's Shiloh speech on pp. 200-202. Weaver's views were not unique to him; others, including some African American intellectuals, made similar points during this period. On this "proto-Garveyism," see Wilson Jeremiah Moses, The Golden Age of Black Nationalism, 1850-1925 (New York, 1978), chap. 10.

90. Waterloo Daily Courier, 11/5/1906; Des Moines Register and Leader, 11/24/1906. William Bell of the Shiloh commission later wrote to Cummins, "Gen. Weaver's address was a grievance to us. I went over it with him [and] had him change it in one particular and I understood it was to be changed in two other objectionable points that were not made." Bell to Cummins, 5/28/1907, Cummins Papers. 91. Hubbell, Grimm, and Garden did not mention the speech; Sherman only commented that Weaver "devoted his attention to an examination of the negro question" (Dedicating in Dixie, 120). The Cedar Rapids Republican, 11/30/1906, approved of Weaver's proposal, though doubting that it could be fully realized. The Des Moines Register and Leader, 11/24/1906, printed the full text of Weaver's speech but dismissed his scheme as impractical before condemning it on moral grounds and concluding that Weaver was "toadying to southern prejudices on a battlefield dedicated to the equality of human rights under the American flag. The occasion and the man both suggested a better use of a great opportunity" $(11 / 25 / 1906)$. The paper also published (11/26/1906) responses to Weaver from S. Joe Brown, an African American lawyer, and writer Leonard Brown.

92. G. W. Crosley to C. W. Kepler, 12/11/1906, Kepler Papers. Crosley continued, "While I am not all in accord with his views, I recognize his right as an Iowa soldier who fought at Shiloh to give expression on that battlefield to such opinions as he might entertain." 
lic that had resulted. He cited words from the Kentucky monument at Chickamauga as evidence of successful reconciliation, reaffirmed by the war with Spain. He closed with a lengthy passage from Joaquin Miller's "Columbus" and its exhortation to "sail on."

By 9:30 the Iowans had re-embarked and were on their way down the Tennessee River bound for Paducah, Kentucky, and a rendezvous with their train. After a pleasant day in the Ohio River town, the group departed shortly before 7 p.m. for Chicago on the Governor's Special. Arriving the following morning, the tourists began to disperse. Those returning to Des Moines pulled into the capital city at 5 p.m. ${ }^{94}$

The members of the various commissions pronounced the tour a resounding success. Merry reported, "I have heard from quite a number of the boys and in every instance they have spoken in the highest terms of the trip." Charles Kepler described it as an "event of a lifetime and never can be duplicated." Members of each commission congratulated one another, feeling that their particular ceremonies had been the highlight of the trip. ${ }^{95}$ The tour had received broad and positive coverage in the Iowa press, and state GAR commander Clark labeled it a "grand and patriotic pilgrimage" whose "effect for good can hardly be estimated."

93. Abernethy, Dedication of Monuments, 277-87. Both Weaver and Kendall were paid $\$ 100$ for their speeches, the going rate for main addresses on the tour. "Expenses Other than Members," Kepler Papers.

94. Abernethy, Dedication of Monuments, 123-28; Hubbell Diary, 11/24/1906.

95. J. F. Merry to C. W. Kepler, 12/8/1906, Kepler Papers; C. W. Kepler to W. H. Michael, 3/29/1907, Letterbooks, 13:385, ibid.; C. W. Kepler to L. S. Tyler, 12/28/1906, ibid., 58-61; John A. Young to Alonzo Abernethy, 12/11/1906, Abernethy Papers.

96. The Des Moines Register and Leader ran articles on 11/11/1906 (an elaborate pictorial spread), 11/12/1906, 11/13/1906, 11/15/1906, 11/16/1906, 11/19/ 1906, 11/20/1906, 11/24/1906, 11/25/1906, and 11/26/1906. For an example of later coverage by smaller papers, see Nashua Reporter, 1/17/1907. The Clark quotation is from the Journal of the 33d Annual Encampment Department of Iowa Grand Army of the Republic, 19. Vicksburg and Chattanooga also seemed pleased with the events they had hosted, as did Paducah. B. W. Griffith (mayor of Vicksburg) to A. B. Cummins, 11/16/1906, Cummins Papers; Vicksburg Herald, 11/16/1906; Chattanooga News, 11/19/1906, Paducah Evening Sun, 11/24/1906. On Chattanooga's active support of Civil War memorialization and tourism, see Anthonette L. McDaniel, "'Just Watch Us Make Things Hum': Chatta- 
Governor Cummins received his share of plaudits. Many people were impressed by his ability to make numerous speeches on the same basic topic without repeating himself. ${ }^{97}$ He also seems to have shored up his support among Iowa veterans. ${ }^{98}$ He moved immediately into the Interstate Convention called to promote the popular election of U.S. senators, held in Des Moines in December. Governor Vardaman of Mississippi, the only southern governor with whom he had shared a platform, telegraphed his support. ${ }^{99}$ The one discordant note was that the tour had overrun its budget by some $\$ 816$. The shortfall was eventually covered by a special legislative appropriation. ${ }^{100}$

The tour may have helped provide some momentum for the highly productive 1907 legislative session. ${ }^{101}$ It also likely contributed to another action that could be seen as part of the state's commemorative arc: the decision to publish a roster of Iowa's Civil War soldiers. The goal of replacing the inadequate 1886 census of former soldiers living in Iowa with an accurate roster had been pressed unsuccessfully by the GAR in the previous two General Assemblies. The effort was renewed - this time successfully - during the 1907 session. ${ }^{102}$ Two commis-

nooga, Adolph S. Ochs, and the Memorialization of the Civil War," East Tennessee Historical Society Publications 61 (1989), 3-14.

97. Cedar Rapids Weekly Gazette, 12/5/1906; Sherman, Dedicating in Dixie, 131.

98. See, for example, E. H. Ely (commander, Iowa City GAR Post) to A. B. Cummins, 2/12/1907, Cummins Papers. Although Cummins lost to William B. Allison in an attempt to secure the Senate nomination in a 1908 primary, after Allison's death he was successful in a special primary despite the attempt by former congressman John F. Lacey, a veteran and a Standpatter, to campaign on the basis that Iowa had never sent a veteran to the Senate.

99. Inter-State Senatorial Amendment Convention Held at Des Moines, Iowa, December 5-6, 1906 (Des Moines, 1907); J. K. Vardaman to A. B. Cummins, 12/3/1906 (telegram), Cummins Papers. Vardaman added that the convention should also consider repealing the Fifteenth Amendment and modifying the Fourteenth.

100. C. W. Kepler to W. B. Bell, 1/5/1907, Letterbooks, 13:100-101, Kepler Papers; J. W. Carson to C. W. Kepler, 1/9/1906, Kepler Papers; Acts and Resolutions of the Thirty-second General Assembly (Des Moines, 1908), chap. 224. Initially, commissioners' expenses were reimbursed at 70 cents on the dollar, and some thought was given to asking them to absorb the balance. For an account of tour expenses, see "Expenses of Members" and "Expenses Other than Members," Kepler Papers.

101. See Sayre, "Cummins," 260-69.

102. The efforts can be followed in the Abernethy Papers. 
sioners, Alonzo Abernethy (LMMR) and George W. Crosley (Shiloh), emerged as leading candidates for the one "old soldier" position on the commission established to produce the roster, with the latter getting the appointment. ${ }^{103}$ It fell to Abernethy, however, to tie up the last loose end of the tour by compiling and editing the official account, published by the state in $1908 .{ }^{10}$

THE IOWA MONUMENTS and the ceremonies that dedicated them provide an interesting commemorative example of what John Bodnar has labeled "official culture." ${ }^{105}$ To say that they embody the state's memory of the Civil War, however, only raises other questions. How does a state determine what it wants to be remembered about a pivotal historical experience? Who was being commemorated? For what purpose?

The "state" was not a disembodied entity that existed independent of human society and politics. Although in theory the state was the people of Iowa, in practice it was their elected representatives and those appointed in accordance with its laws (which is not to imply that those elected and appointed were a faithful mirror of the state's population). Arguably, it also included those with the ability to influence its actions. Within the body politic of Iowa, "old soldiers" were a respected and im-

103. The appointment was made on the recommendation of GAR Department Commander George A. Clark. Crosley actively campaigned for the position, using his influence with his friend Charles Aldrich, curator of the State Historical Department (and a tour participant). Crosley felt that since Abernethy had recently been reappointed to the state university's Board of Regents, he should not have sought a second state appointment. See Crosley to Aldrich, 4/10/1907, Aldrich Papers, SHSI-DM. Crosley later wrote consolingly to Abernethy, attributing his appointment to the fact that he had known Clark when the latter had lived in Webster City. Crosley to Abernethy, 5/15/1907, Abernethy Papers.

104. Abernethy described the process of compiling the volume in a long letter to D. W. Reed, 4/13/1908, Abernethy Papers. Reed had complained that his name had been left off the Shiloh map included in the volume and that G. O. Morgridge had been allowed to insert a paragraph indicating that he had not approved Reed's description of the 11th Iowa's position on its monument.

105. John Bodnar, Remaking America: Public Memory, Commemoration, and Patriotism in the Twentieth Century (Princeton, NJ, 1992), chap. 1. According to Bodnar (13), "Public memory emerges from the intersection of official and vernacular expressions," a process that is very much a contested one. 
portant group. As Grenville Dodge noted in a 1907 political analysis he did for Senator Allison, Union veterans and their descendants were the one element of the electorate that could be found in every township in the state. Virtually every officeholder or aspirant sought to keep on their good side. ${ }^{106}$ The GAR, the largest veterans' group by far, had a quasi-official status, with quarters in the state capitol and a modest annual appropriation. ${ }^{107}$ Questions of commemoration required the participation and at least tacit approval of the veteran community; hence the use of appointed commissions of veterans described above.

The commissions determined the style and substance of the state's commemorative efforts in the battlefield parks. The commissioners who planned the monuments and dedication ceremonies were not, however, generally typical of Iowa veterans. The vast majority of them were GAR members, but that group probably represented a minority among Union veterans. ${ }^{108}$ Moreover, a clear majority of the commissioners (23 of 36) had mustered out as officers in contrast to the much more common experience of enlisted service. ${ }^{109}$

Those who had been officers were eligible for membership in the Military Order of the Loyal Legion of the United States (MOLLUS), which provided another potential source of influence on the commissioners. This intentionally hereditary organization had a single chapter, or commandery, in Iowa, which

106. "1907," Dodge Biographical Record, 19:429-41, Grenville Dodge Papers. For statements about the electoral importance of veterans, see, for example, C. E. Pickett, Third District congressman, to A. H. Peters, 2/17/1911, Pickett Papers, UI-SC; and J. R. McCallum to G. N. Haugen, Fourth District congressman, 2/25/1902, Gilbert Haugen Papers, SHSI-IC.

107. In 1892 the GAR was given quarters in the basement of the capitol. M. M. McFarland (secretary of state) to M. L. Leonard, 9/14/1892, GAR Collection. It maintained a presence there until 1954. Iowa Official Register for 1953-54 (Des Moines, 1954), 212. An annual appropriation (\$600 in 1906) underwrote use of those quarters.

108. Nationally, at its peak in 1890 the GAR enrolled about one-third of Union veterans. Stuart McConnell, Glorious Contentment: The Grand Army of the Republic, 1865-1900 (Chapel Hill, NC, 1992), 54.

109. These totals are based on the commissions' membership in 1906. One commissioner, A. J. Miller of the 6th Iowa, served on two commissions (Shiloh and LMMR). 
met five times per year. ${ }^{110}$ Although many were likely put off by its relatively steep admission fee of $\$ 25$ and annual dues of $\$ 5$, it did have a membership of 262 in the state by $1906 .{ }^{111}$ Its proceedings featured the reading of papers on the war, in contrast to the GAR's less formal campfires. ${ }^{112}$ Many combined membership in both organizations, but some thought that the Loyal Legion harbored elitist pretensions, and some tension between the two was occasionally evident. ${ }^{113}$ At least 12 of the monument commissioners were MOLLUS members; each commission included at least one member. ${ }^{114}$

The commissioners were also men of some means. The nature of the appointments, which required travel to battlefields and meetings and offered remuneration only for expenses, put participation out of reach of those who could not arrange their own schedules and afford time away from earning a livelihood. In general, they were professional men. The 11 members of the

110. On the Loyal Legion generally, see Robert Girard Carroon and Dana B. Shoaf, Union Blue: The History of the Military Order of the Loyal Legion of the United States (Shippensburg, PA, 2001), which contains a useful roster of companions (members) of the first class (officer veterans of the war) and third class (honorary members selected by the commanderies up until April 1890).

111. MOLLUS Rules and Regulations of the Commandery of Iowa, Kepler Papers; E. D. Hadley to Companions, 8/15/1917, Kepler Papers; Register of the Military Order of the Loyal Legion of the United States, comp. J. Harris Aubin (Boston, 1906), 6. The 262 includes 68 who qualified as sons of veterans (companions of the second class) and one honorary member.

112. The Iowa commandery had previously published two sets of papers. War Sketches and Incidents as Related by Companions of the Iowa Commandery Military Order of the Loyal Legion of the United States, 2 vols. (Des Moines, 1893, 1897; reprint ed., 1994).

113. See, for example, G. W. Crosley to Charles Aldrich, 3/11/1892, Aldrich Papers. Writing in regard to an unnamed piece of legislation both men favored, Crosley noted, "There is a feeling of jealousy on the part of the GAR towards the Loyal Legion which might somewhat interfere with the weight of the Loyal Legion endorsement among that class of fellows in the house." On this topic generally, see Dana B. Shoaf, "'Every Man Who Wore the Blue': The Military Order of the Loyal Legion of the United States and the Charges of Elitism after the Civil War," in Union Soldiers and the Northern Home Front: Wartime Experiences, Postwar Adjustments, ed. Paul A. Cimbala and Randall M. Miller (New York, 2002), 463-81.

114. This is the number that can be identified from the roster in Carroon and Shoaf, Union Blue, 149-402. Seven of these had papers published in War Sketches and Incidents. 
Shiloh commission, for example, included a doctor, three lawyers, a carriage manufacturer, a newspaper publisher, two insurance executives, a prosperous farmer, and a judge..$^{115}$

As the Shiloh inscriptions controversy demonstrated, regimental identity was vitally important to Civil War veterans. In this regard, it is worth noting that not all Iowa Civil War regiments were formally commemorated - only those who fought at Shiloh, Vicksburg, and Chattanooga. This essentially limited memorialization to units that had been part of the Army of the Tennessee; those whose service had been elsewhere, notably in the trans-Mississippi theater or on the frontier, were omitted from this form of the state's official memory. The 32 units that fought at Vicksburg, where the Army of the Tennessee was temporarily expanded by the addition of formations that would not stay with it, guaranteed that the majority of the state's regiments were commemorated on at least one monument. Some 25 regiments and batteries were not, however, including most of Iowa's cavalry regiments and its only African American regiment. ${ }^{116}$

An even larger number of veterans were also outside the state's official commemorative efforts - those who had served in non-Iowa units. Given Iowa's rapid population growth after the war, these had become a majority of the veterans living in the state by the 1880s. Although the 1886 List of Ex-Soldiers, Sailors, and Marines Living in Iowa was notoriously inaccurate in its details, there is no reason to doubt the broad picture that it painted. Of 39,114 Civil War veterans listed as living in the state, 22,241 (56.9 percent) were reported as having served in out-ofstate units. ${ }^{117}$ What this meant at the local level was captured by

115. These were, respectively, G. O. Morgridge, G. L. Godfrey, C. W. Kepler, E. B. Soper, W. B. Bell, A. J. Miller, G. W. Crosley, J. Hayes, D. Matson, and R. G. Reiniger. The occupations are obtained from a variety of biographical dictionaries and correspondence with C. W. Kepler. I have not been able to identify J. W. Carson's occupation.

116. Those not specifically commemorated included the 1st, 18th, 27th, 29th, 32nd, 33rd, 36th, 37th, 39th, 41st, 44th, 45th, 46th, 47th, 48th, and 1st Iowa (African Descent) infantry regiments, the $3 \mathrm{rd}$ and 4 th batteries, and the 1 st, 2 nd, and 5 th through 9 th cavalry regiments. The often detached nature of cavalry operations meant that cavalry units tended to be found away from the large concentrations of infantry engaged in major battles.

117. List of Ex-Soldiers, Sailors and Marines Living in Iowa, Prepared by William L. Alexander, Adjutant-General (Des Moines, 1886). This total was reached by inte- 
the author of a history of Greene County published in 1907. He noted that of the 150 soldiers who had enlisted from the county during the war, "not a dozen" of these still lived in it. On the other hand, some 200 veterans lived in the county, representing "more than fifty regiments from half that number of states."118 There was, of course, no effort to snub those veterans who moved into the state after the war. Such "immigrants" were well integrated into the Iowa GAR, often making up the majority of post members and periodically holding its highest offices. ${ }^{119}$ Local monuments sometimes listed members of the community who served in out-of-state regiments. ${ }^{120}$ Still, the tour was not overrun with them: only 13 participants can be identified whose service was with non-Iowa regiments. ${ }^{121}$

The creation of the battlefield monuments and their dedication was also a very masculine process. The all-veteran composition of the marking and monument commissions, of course, ensured that no women would be represented there, and apart

grating those listed in the addendum into the totals and subtracting out veterans of other wars or peacetime service. It also does not include the 211 naval veterans of the war who are listed.

118. E. B. Stillman, The Past and Present of Greene County, Iowa (Chicago, 1907), 85. This is not to argue that veterans were more mobile than the general population. A study of Dubuque's experience found that veterans were more likely to remain in the community than non-veterans. Russell L. Johnson, "The Civil War Generation: Military Service and Mobility in Dubuque, Iowa, 1860-1870," Journal of Social History 32 (1999), 791-820.

119. For example, the roster of the post to which Andersonville commission member M. V. B. Evans belonged (Beaman in Grundy County) has been published; of its 91 members, only 19 had served in Iowa units (35 had served in Illinois regiments). Civil War Veterans: Members of the Andersonville Post of the Grand Army of the Republic, Post 155 (Des Moines, 1976). Of the 26 men who served as department commanders between 1880 and 1906, 16 had served in non-Iowa units. Figures compiled from Swisher, Department of Iowa, GAR.

120. The 1886 act that gave county governments the authority to levy a tax (after a referendum) to build soldiers' monuments required that the names of all deceased soldiers and sailors who entered service from the county be listed. It gave the GAR posts of the county the discretion to list other deceased soldiers, such as those who may have entered the service from other counties or states. Acts and Resolutions of the Twenty-first General Assembly, chap. 62.

121. Two of these were Andersonville commissioners; three others had parts in one or more programs. This figure was reached by checking the list of participants against the National Park System's Civil War Soldiers and Sailors data base. There quite possibly were more. 
from T. A. R. Kitson's contributions to the Vicksburg monument, only men were involved in fashioning the monuments. The 35 women and girls who were on the tour went largely in the capacity of wives and daughters of veterans, and apart from a few who unveiled monuments, they had no part in the ceremonies. ${ }^{122}$

Such nearly exclusive maleness was not necessarily the norm in other commemorative activities in Iowa. Harriett Ketchum of Mount Pleasant provided the original design for the Soldiers and Sailors Monument in Des Moines, and Cora C. Weed of Muscatine was a member of the commission that oversaw the project. ${ }^{123}$ Women were more involved in Civil War commemoration at the local level, where tents (local chapters) of the Woman's Relief Corps (WRC) were often the driving force behind memorial projects, and other women's organizations such as the Ladies of the GAR, and the Daughters of Veterans were sometimes involved. ${ }^{124}$ Indeed, all three groups had recognized, if clearly subordinate, roles at the annual state GAR encampment. ${ }^{125}$ There were no such roles on the 1906 tour. Charles A. Clark, the GAR state commander was present and gave the major address at Vicksburg, but neither Addie E. Unangst of Davenport, the president of the Iowa WRC, nor any of its officers participated.

The men and women on the tour had one thing in common apart from an interest in commemoration: their race. African American members were scattered among the state's GAR posts, but none were on the tour. The one black regiment credited to the state, the 60th U.S. Colored Troops (also known as the 1st Iowa African Descent), had spent the war in Arkansas and Missouri and was not engaged in any of the battles commemorated.

122. By contrast, when the Indiana monument was dedicated at Andersonville in 1908, two of the speakers were women. Madison, "Civil War Memories and 'Pardnership Forgittin',' 218.

123. Weed, Handbook of Iowa Soldiers' and Sailors' Monument, 3, 9.

124. At least 68 local monuments in Iowa either mention the WRC's involvement or display its badge; another three were erected by the Ladies of the GAR. 125. See, for example Journal of the 32d Annual Encampment, Department of Iowa Grand Army of the Republic.

126. For a list of WRC departmental officers, see History of the Department of Iowa Woman's Relief Corps Auxiliary to the Grand Army of the Republic, comp. Emma B. Robinson (n.p., n.d.), 18. 
Although it was acknowledged in the roster of Iowa troops compiled after the tour, the 60th (possibly because of its high number) had come last among infantry regiments when flags were deposited in the state capitol. ${ }^{127}$ Even though two of the commissioners had served as officers in the USCT, the state's collective remembrance took little notice of African American participation in the war. ${ }^{128}$ On the battlefields visited, the most likely place for this to have happened would have been Vicksburg. Black units had participated in some of the campaign's outlying engagements, particularly at Milliken's Bend, Louisiana (June 7, 1863). There several recently organized USCT regiments had fought well alongside several companies of the 23rd Iowa. The Vicksburg monuments and ceremonies took no notice of that battle, however; as close as it gets to the state's official record is a brief line in the marking commission's 1901 report that noted the presence of "a small brigade of untrained colored troops." ${ }^{129}$ The tendency to overlook the role of African American troops may derive partly from the domination of Iowa's remembrance by the Army of the Tennessee. Army commander William T. Sherman's resistance to having black troops in his army was well known and only ended late in the war by a direct order and visit from the secretary of war. ${ }^{130}$

127. Roster and Record of Iowa Soldiers in the War of the Rebellion, 6 vols. (Des Moines, 1908-11); Report of the Battle-Flag Committee. On the 60th USCT, see David Brodnax Sr., "'Will They Fight? Ask the Enemy': Iowa's African American Regiment in the Civil War," Annals of Iowa 66 (2007), 266-92; and William S. Morris, "Black Iowans in Defense of the Nation, 1863-1991," in Outside In: African-American History in Iowa, 1838-2000, ed. Bill Silag (Des Moines, 2001), 97-99.

128. Daniel Matson of the Shiloh commission and W. H. C. Jacques of the Vicksburg commission had gone from enlisted service in Iowa regiments to service as officers in the USCT. Matson's Loyal Legion paper, "The Colored Man and the Civil War," in War Sketches and Incidents, 2:236-54, presents a positive, though patronizing, view of African American troops' contribution to the Union cause, but notes, "We do not claim for them as possessing the intelligence, the self-reliance, or the courage of our white troops" (244).

129. Commissioners' Report, 26. For recent studies of Milliken's Bend, see Richard Lowe, "Battle on the Levee: The Fight at Milliken's Bend," in Black Soldiers in Blue: African Americans Troops in the Civil War Era, ed. John David Smith (Chapel Hill, NC, 2002), 207-32; and Mark Ehlers, "Seeing the Elephant: Milliken's Bend, Louisiana, 1863," War E Society 25 (2006), 21-34.

130. On Sherman's attitude toward the use of African Americans as soldiers, see Michael Fellman, Citizen Sherman: A Life of William Tecumseh Sherman (New 
Lack of notice of the USCT is but part of the larger question of race in the memory of the war, and we may ask to what extent race and slavery figured in the dedication tour. The short answer is that it was neither a major presence nor was it entirely absent. Questions of race relations did arise. Ernest Sherman noted that during the stopover at Atlanta the bloody race riot that had occurred there just two months earlier was a major topic of discussion. In general, he framed race relations as a labor problem rather than an issue of civil rights. ${ }^{131}$ There were a few references to emancipation in some of the dedication speeches, but they functioned largely as adornments to other points; there was little attempt to probe the realities of postemancipation life. Only James B. Weaver had addressed the question squarely, if singularly. Abernethy certainly emphasized the centrality of slavery as a cause of the war in his introduction to The Dedication of Monuments, portraying it as the primary spur to secession. Despite his abolitionist background, though, he did not stress the importance of slavery's destruction or its implication of equality in race relations.

Some Iowa veterans were clearly aware of the connection between the war and the future of race relations. George W. Crosley, while defending Weaver's right to speak as he did, foresaw a different eventual outcome to what he termed "the

York, 1995), 155-65. U.S. Grant had preceded Sherman as the army's commander. Although he became a strong proponent of black troops later in the war, Grant's attitude evolved over time; no African Americans were actually assigned to the Army of the Tennessee during his tenure as its commander. See Brooks D. Simpson, "Quandaries of Command: Ulysses S. Grant and Black Soldiers," in Union and Emancipation: Essays on Politics and Race in the Civil War Era, ed. David W. Blight and Brooks D. Simpson (Kent, OH, 1997), 123-49.

131. Sherman, Dedicating in Dixie, 71-72. "The fact is everywhere apparent that the white people of the South have on hand a very difficult problem to solve in the matter of the negro." Sherman felt that black suffrage had been a mistake: "It would have been far wiser to have placed the negro on an equal political footing with the Indian - or woman, giving him full property and personal rights, but with-holding the ballot" (73). On the Atlanta race riot, see Gregory Mixon, The Atlanta Riot: Race, Class, and Violence in a New South City (Gainesville, FL, 2005); and David Fort Godshalk, Veiled Visions: The 1906 Atlanta Race Riot and the Reshaping of American Race Relations (Chapel Hill, NC, 2005).

132. Dedication of Monuments, 14. Abernethy also cited the doctrine of states' rights as a contributing factor. 
great race problem which had such intimate connection with the great struggle in which we were engaged then, and which has so much importance to day as affecting the destiny of millions of our citizens who must be recognized as equal before the laws of both God and man.... We did our whole duty at Shiloh and on other battlefields to get the solution of the race problem started right; it remains for our posterity to determine the solution along the lines of eternal justice and it will correctly be solved along those lines." ${ }^{133}$ After returning from the tour, Charles Kepler wrote to the pastor of the AME church he and a group of tour participants had visited in Atlanta, assuring him that "we people in the North are very much interested in the welfare of the colored people in the South, and want them to have equal chances in life." ${ }^{134}$ Alonzo Abernethy had earlier responded to the unsolicited gift of an advance copy of a new edition of Thomas Dixon's The Leopard's Spots by telling the author, "I do not agree with your views regarding the negro and doubt if the work will tend to promote the final settlement of this great moral and industrial problem"; he felt constrained to add, however, that "time may prove that my wife's hearty endorsement of the work to be the more correct view." ${ }^{135}$ There was in these egalitarian expressions a resignation to current conditions and certainly no sense of urgency.

Iowa's overwhelmingly white demographic composition likely contributed to the tendency to overlook the racial content and consequences of the war. Alhough the war had led to noticeable growth in the number of African Americans in the state, they still constituted less than one percent of the state's popula-

133. G. W. Crosley to C. W. Kepler, 12/11/1906, Kepler Papers.

134. C. W. Kepler to Rev. J. A. Rush, 12/29/1906, Letterbooks, 13:65-66, ibid. How much this attitude derived from Kepler's view of the war is unclear. The year before he had told a reunion: "The only issues were for and against the Union; of course in the North there were a few little imaginary issues harped on by the Copperheads." Minutes, 2nd Iowa Cavalry Association, Biennial Reunion, UI-SC.

135. Alonzo Abernethy to Rev. Thomas Dixon, 10/5/1903 (copy), Abernethy Papers. Abernethy went on to tell Dixon that the two copies of the first edition were in constant circulation from the Osage Public Library. On the connection between the tendency to discuss race as a "problem" and reconciliation, see Blight, Race and Reunion, 364-65. 
tion in $1900 \cdot{ }^{136}$ For its part, Iowa's African American community seems to have focused its historical memory more on celebrating emancipation rather than dwelling on the military experience of the war itself. ${ }^{137}$ Most theories of collective memory, drawing on Maurice Halbwachs's seminal work, point out the selective and socially constructed nature of the phenomenon; what is not usable in the present tends to be forgotten or consigned to history. ${ }^{138}$ In the racialist climate of the early twentieth century (evident also in the Anglo-Saxonism of some of the speeches), an emancipationist or racially egalitarian memory of the Civil War would sadly not have seemed to offer white Americans much in the way of a usable past.

Was the main thrust of the tour simply reconciliation, then? Enough dedication speeches in this vein have been cited above, beginning with Cummins's speech at Vicksburg, to make this a plausible interpretation of the tour and put Iowa's efforts in the company of most other states. ${ }^{139}$ Yet such a characterization would not fully capture the veterans' remembrance of the war or their view of their former adversaries.

In the first place, the reconciliation achieved was no intersectional love feast in which Union veterans rushed to embrace their former enemies, certainly not on the basis of moral equality. A number of recent studies have reminded us of the clear limits that Union veterans placed on the process of reconciliation, especially in matters involving potent symbols (such as displaying or returning Confederate battle flags), federal assistance to Confederate veterans, and a general dislike of Lost

136. See Willis Goudy, "Selected Demographics: Iowa's African-American Residents, 1840-2000," in Outside In, 22-41. See also Leslie A. Schwalm, Emancipation's Diaspora: Race and Reconstruction in the Upper Midwest (Chapel Hill, NC, 2009).

137. Schwalm, "Emancipation Day Celebrations," 291-332, points out that by the end the end of the nineteenth century, the emphasis in such celebrations was shifting from remembrance of slavery and the process of emancipation to an emphasis on racial uplift.

138. See Jeffrey K. Olick, "Collective Memory," and Patrick H. Hutton, "Memory," in International Encyclopedia of the Social Sciences, 2nd ed., 9 vols. (New York, 2007), 2:7-8, 5:74-76.

139. See, for example, the account of dedication speeches at Shiloh in Timothy B. Smith, "Shiloh's Monument Dedication Speeches and the Rhetoric of Reunion," in Untold Story of Shiloh, 97-138. 
Cause celebrationism. ${ }^{140}$ Similar evidence is not hard to find among the Iowans involved in fashioning this particular episode of official memory. As John Hayes wrote, "Nowadays, we gloss it over, are all one family, the gray on a par with the blue etc. Rot. We struggled to save the Union, they to destroy it and Black cannot be white, at least while Andersonville remains. I hope it may be preserved as it now is, a monument to their infamy to the end of time." ${ }^{\prime 141}$ Andersonville, indeed, remained a sore point, probably made more so by the United Daughters of the Confederacy's announced plans to erect a monument to the prison's executed commandant, Henry Wirz. ${ }^{142}$ The change in the tour's overall tone there was marked, and Andersonville was the only dedication where the state's published account of its proceedings was supplemented by the addition of substantial outside material, specifically former Iowa lieutenant-governor Benjamin Gue's description of his 1884 visit to the site of the prison and a black-bordered list of 214 Iowans interred in the cemetery there, both of which emphasized the cruel conditions experienced by Union prisoners of war. Although the memory of wartime treatment of prisoners has long been recognized as a barrier to reconciliation, the full story of Andersonville's role in complicating the process is only now being explored. Its impact on Iowa veterans was lasting. ${ }^{143}$

140. See, for example, John R. Neff, Honoring the Civil War Dead: Commemoration and the Problem of Reconciliation (Lawrence, KS, 2005); Larry M. Logue, To Appomattox and Beyond: The Civil War Soldier in War and Peace (Chicago, 1996); M. Keith Harris, "Slavery, Emancipation, and Veterans of the Union Cause: Commemorating Freedom in the Era of Reconciliation, 1885-1915," Civil War History 53 (2007), 264-99. Confederate veterans, of course, also placed their own limits on the process.

141. Hayes to C. W. Kepler, 12/11/1906, Kepler Papers.

142. Atlanta Constitution, 11/16/1906; Sherman, Dedicating in Dixie, 54.

143. Abernethy, Dedication of Monuments, 108-26; D. C. Bishard to Alonzo Abernethy, 1/15/1907, and Abernethy to Bishard [n.d., likely January 1907], Abernethy Papers; Paul H. Buck, The Road to Reunion, 1865-1900 (Boston, 1937), 4850; Robert Scott Davis, Ghosts and Shadows of Andersonville: Essays on the Secret Social Histories of America's Deadliest Prison (Macon, GA, 2006); Nancy Roberts, "The Afterlife of Civil War Prisons and their Dead" (Ph.D. diss., University of Oregon, 1996); Douglas Gibson Gardner, "Andersonville and American Memory: Civil War Prisoners and Narratives of Suffering and Redemption" (Ph.D. diss., Miami University, 1999); Benjamin Gregory Cloyd, "Civil War Prisons in American Memory" (Ph.D. diss., Louisiana State University, 2005); J. W. Cheek 
Some Iowans, such as Rigby, were genuine reconciliationists, and some remarked on the material progress the South had made since the war, especially in its cities. ${ }^{144}$ More, though, seem to have been unimpressed by what they saw. Ernest Sherman noted how surprised many of the tourists seemed when the Governor's Special passed through a pastoral stretch of country near Montgomery that somewhat resembled Iowa; in general, they were more likely to draw unfavorable contrasts. ${ }^{145}$

There were also concerns that former Confederates were insincere about accepting the war's results. Iowa newspapers, like those in other northern states, followed the dedication of Confederate monuments with an almost morbid curiosity, and the GAR periodically protested against suggested federal aid to former Confederates and various manifestations of the Lost Cause. ${ }^{146}$ H. C. McArthur, one of the speakers at Shiloh, had described Charleston, South Carolina, in 1902 as "a bad old rebel town" where American flags were scarce and the dominant desire was a "longing for de good old days befo' de wah." Charles Kepler accompanied an enthusiastic account of the tour in a letter to his brother-in-law with the observation that "by the way they are just as big rebels now as they ever were." ${ }^{147}$

to C. W. Kepler, 3/24/1912, Kepler Papers. When the Soldiers and Sailors Monument at the Iowa Capitol was finally dedicated in 1945, Andersonville was one of the experiences invoked by speaker Ora B. Williams; see "In Honor of Iowa Soldiers," Annals of Iowa 27 (1945), 151-57.

144. See, for example, Rigby's extensive correspondence with former Confederate general Stephen D. Lee, Rigby Papers, and his remarks to a reunion of the 24th Iowa, 9/18/1899, in which he urges reconciliation. See undated typescript, "Horace to the Athenians after the Civil War," ibid.

145. Sherman, Dedicating in Dixie, 38, 72. Robert Garden characterized western Tennessee as "fifty years behind the times." History of Scott Township, 198-99.

146. For the former, see, for example, Davenport Gazette, 4/29/1886; Des Moines Daily Capitol, 7/14/1900; and Davenport Republican, 9/17/1902. For the latter, see Samuel J. Kirkwood Post No. 9 (Iowa City), Minute Book 4, 8/30/1906 (resolution against a federal appropriation for headstones for Confederate prisoners buried in the North), and 1/26/1908 (resolutions against federal pensions for Confederate veterans and monument to Wirz) and "Report of Robert Kissack, Patriotic Instructor," Journal of the 33rd Annual Encampment, Department of Iowa, Grand Army of the Republic (1907), 31 (against adulation of Robert E. Lee).

147. H. C. McArthur to C. W. Kepler, 2/21/1902, Kepler Papers; C. W. Kepler to J. R. McClaskey, 12/24 /1906, Letterbooks, 13:41, ibid. 
By far the most common theme of the dedication speeches was that the purpose of the war was the preservation of the Union, often buttressed by references to the country's general prosperity and recently established status as a world power. All that was "proof" that the Union cause was right, and even the South had benefited. The central emblem of both wartime cause and the current state of affairs was the American flag, or as it was usually put, the "old flag.." ${ }^{148}$ The war could thus be seen as preservative and defensive in nature. Indeed, one of the state's earliest commemorative acts, in 1887, was to inscribe on the cornerstone of the new Soldiers Home in Marshalltown, "Iowa forgets not the defenders of the Union," a sentiment that would be echoed on many local monuments around the state. ${ }^{149}$ This tendency to see the war as defensive in character, even though it had been fought largely on southern soil, perhaps also made it more difficult to conceptualize the war as innovative - much less revolutionary - in its racial implications.

The logic of this restorative view of the war did require - at least at the symbolic level - some measure of reconciliation with former foes. Thus, in his introduction to The Dedication of Monuments, Alonzo Abernethy quoted Shiloh park commissioner Josiah Patterson's words at the Ohio dedication three years earlier: "The American people once had a cause of war which they settled by an appeal to the sword without dishonor to either side. The [monuments] mutely bear witness that it is impossible for another Ireland, or another Poland, to exist in America. They give expression to a national epic, the grandest and the noblest in the annals of time." ${ }^{150}$ Had the white South remained unreconciled to the Union - or, worse, turned into a Poland or an Ireland continuing to strive for independence within an American Empire maintained by coercion - the North's victory would have seemed hollow.

The reconciliationist impulse was likely undergirded by the tendency of veterans on both sides to remember the war in

148. These themes are broadly consistent with the GAR view of the war as detailed in McConnell, Glorious Contentment, 170-238.

149. Iowa State Reporter (Waterloo), 12/8/1887. The stone is now at the base of the central flagpole at what has become the Iowa Veterans Home.

150. Abernethy, Dedication of Monuments, 15. 
terms of intense personal experiences such as combat, danger, and privation. These could be especially aroused by revisiting battlefields. ${ }^{151}$ Knowledge that both sides had had similar experiences made it possible to at least acknowledge the other side's bravery. In a letter that otherwise evoked the memory of Andersonville and railed against the prospect of federally funded monuments to Confederates at Vicksburg, veteran Jessie Cheek could still write to Charles Kepler, "You and I do not have to have a monument put up anywhere to tell us the southern soldier was brave. We know they were. You and I both have seen the time when they were a little too darn brave to suit either of us." ${ }^{152}$

Participation by Confederate veterans at dedications in the battlefield parks (if not at Andersonville) thus offered the needed validation by the defeated South that the North's triumph left everyone better off. (The anti-southern sentiments often expressed by northern veterans can thus be seen as examples of vernacular rather than official memory.) Bearing in mind the mixed nature of the response of Iowa veterans to the South and to their former foes, perhaps "unionist" rather than "reconciliationist" is the most appropriate label for the state's commemorative narrative. One suspects that the veterans would find surprising our tendency to see "reconciliationist" and "emancipationist" memories of the war as antithetical, as both could be incorporated in - and subordinated to - a master narrative stressing the perpetuation of the Union. ${ }^{153}$ They would probably find even more surprising (and deeply disturbing) the extent to which the "Union Cause" has ceased to matter in popular conceptions of the war. ${ }^{154}$

151. For example, at Shiloh, Robert Garden reflected, "Everything seemed to be passing in panoramic view before my vision every incident recurring to my memory as though it were but yesterday." History of Scott Township, 201.

152. J. W. Cheek to C. W. Kepler, 3/24/1912, Kepler Papers. Both Cheek and Kepler were wounded in the war.

153. See, for example, Grant's memoirs and Joan Waugh, "Personal Memoirs of U. S. Grant: A History of the Union Cause," in More than a Contest between Armies: Essays on the Civil War Era, ed. James Marten and A. Kristen Foster (Kent, OH, 2008), 219-49.

154. See Gary W. Gallagher, Causes Won, Lost, and Forgotten: How Hollywood and Popular Art Shape What We Know about the Civil War (Chapel Hill, NC, 2008), esp. chap. 3. 
LIKE MOST COLLECTIVE MEMORIES, the one Iowa commemorated at Shiloh, Vicksburg, Chattanooga, and Andersonville in 1906 was selective: a unique and successful war in defense of the "old flag" and the Union it represented, conducted by the white citizen soldiers of the Iowa regiments of the Army of the Tennessee. The successful perpetuation of the Union made some degree of reconciliation with the defeated South necessary, while references to freedom and the Declaration of Independence's invocation of equality added luster to the Union's victory. The counter-memory of Andersonville and doubts about the South, however, ensured that reconciliation was not total. Above all, the Union had been saved and the young state of Iowa had more than done its part. 